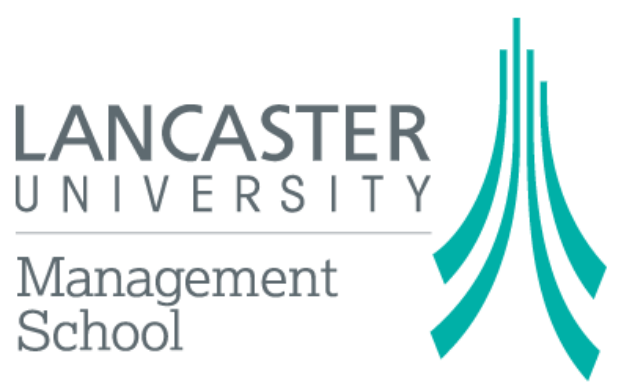

Economics Working Paper Series

2014/019

\title{
The Development Push of Refugees: Evidence from Tanzania
}

Jean-François Maystadt and Gilles Duranton

The Department of Economics Lancaster University Management School

Lancaster LA1 4YX

UK

All rights reserved. Short sections of text, not to exceed two paragraphs, may be quoted without explicit permission, provided that full acknowledgement is given. 


\title{
The Development Push of Refugees : Evidence from
}

\author{
Tanzania* \\ Jean-François Maystadt ${ }^{\dagger} \quad$ Gilles Duranton ${ }^{\ddagger}$
}

October 2014

\begin{abstract}
We exploit a 1991-2010 Tanzanian household panel to assess the effects of the temporary refugee inflows originating from Burundi (1993) and Rwanda (1994). We find that the refugee presence has had a persistent and positive impact on the welfare of the local population. We investigate the possible channels of transmission, underscoring the importance of a decrease in transport costs as a key driver of this persistent change in welfare. We interpret these findings as the ability of a temporary shock to induce a persistent shift in the equilibrium through subsequent investments rather than a switch to a new equilibrium in a multiple-equilibrium setting.
\end{abstract}

Keywords: Refugees; Tanzania; Multiple equilibrium; Roads.

JEL Classification: I32; O18; Q54

${ }^{*}$ The first author is grateful to the Centre for Institutions and Economic Performance (LICOS), KU Leuven and the International Food Policy Research Institute (IFPRI) for their support during his post-doctoral position, during which that research was initiated. We thank Jenny Aker, Jennifer Alix-Garcia, Olivier Bakewell, Michael Clemens, Mathias Czaika, Kalle Hirvonen, Michael Lipton, Walter Steingress, Jacques Thisse and participants in the Migration and Development Conference (Oxford), the LICOS seminar (Leuven, Belgium), the Sussex seminar (Brighton, UK), the IFPRI seminar (Washington DC), the Lancaster seminar, the Centre for Research in Economic Development workshop (Namur, Belgium), the Centre for the Study of African Economies conference (Oxford), the Royal Economic Society meeting (London) and the Households in Conflict Network workshop (Berkeley, CA, US) for their comments and suggestions. We are also indebted to the World Bank and Kathleen Beegle for granting access to confidential geographic data of the Kagera Health and Demographic Surveys. We specially thank Joachim De Weerdt (Economic Development Initiatives) and Kalle Hirvonen (IFPRI) for their help with the data and for sharing some of their own constructed data. Jose Funes provided valuable research assistance with GIS data. J.-F. Maystadt acknowledges financial support from the IFPRI Strategic Innovation Funds, the CGIAR Research Program on Policies, Institutions, and Markets, and the KU Leuven research fund (Methusalem).

${ }^{\dagger}$ Department of Economics, Lancaster University Management School, Lancaster, LA1 4YX, UK. Email: j.maystadtelancaster.ac.uk.

${ }^{\ddagger}$ Wharton School, University of Pennsylvania, Philadelphia, PA 19104; and Centre for Economic Policy Research (CEPR). Email: duranton@wharton . upenn.edu. 


\section{Introduction}

What are the long-term effects of temporary population shocks? Are these effects, if any, caused by a switch of equilibrium in a multiple-equilibrium setting, or are they the consequence of post-shock investments that shift the supply curve and thus the equilibrium? In the case of a shift in equilibrium, what are the investments that drive this shift? To answer these questions we exploit a 1991-2010 Tanzanian household panel to assess the effects of the inflow of temporary refugees originating from Burundi (1993) and Rwanda (1994). We find that the refugee presence has a persistent and positive impact on the welfare of the local population. We investigate the possible channels of transmission, underscoring the importance of a decrease in transport costs. We interpret these findings as the ability of a temporary shock to induce a persistent shift of the equilibrium through subsequent infrastructure investments rather than a switch to a new equilibrium in a multiple-equilibrium setting.

These findings are important because large population shocks occur frequently and are often the source of considerable social tensions. After World War II, the newly-established United Nations High Commissioner for Refugees (UNHCR) recognized the existence of 400,000 refugees. The decolonization period, as well as the resurgence of civil wars after the end of the Cold War, led to a rapid increase in the number of people seeking protection in foreign countries, including the mass flights of Kurds from Northern Iraq, refugees fleeing inter-ethnic violence in former Yugoslavia, and the more than 2 million Rwandans fleeing to former Zaire, Tanzania, Burundi, and Uganda in 1994. UNHCR (2012) reported about 8.4 million refugees in developing countries in 2011.

Importantly, about 70 percent of refugees have that status for more than five years so their presence may have far-reaching consequences on their local hosts, as they interact with the host economies. Furthermore, most refugees are hosted by their neighboring countries, not necessarily facing much better economic conditions. The Horn of Africa offers a recent example (UNHCR, 2012). Repeated violence, combined with a severe drought in 2011, is responsible for more than 1 million Somali refugees, who are almost exclusively hosted in neighboring countries such as Kenya, Ethiopia, Yemen, Djibouti and Eritrea. Recent conflicts in Syria have also been followed by the inflow of hundreds of thousands of people hosted mainly in neighboring countries such as Turkey, Lebanon, Jordan, or Iraq.

These patterns of forced migration flows into neighboring countries have led some scholars to argue 
that such population shocks may explain the existence of conflict spillovers by creating political and social tensions in hosting countries (Azam and Hoeffler, 2002; Salehyan, 2008). Montalvo and Reynal-Querol (2007) have also warned against the risk of malaria propagation in refugee-receiving countries. However, these cross-country analyses face the challenges of distinguishing the causal impact of refugees from that of other conflict spillovers and identifying specific channels of transmission. Assessing the consequences of major flows of forced migrants across areas of the same country that have been differently exposed to the presence of refugees should allow for a better identification of these channels and will better inform policies to accompany these shocks in the future.

Furthermore, whether the changes in the host economy after the departure of refugees result from a switch to a new (and better) equilibrium or from a shift in the existing equilibrium is of fundamental policy importance. The existence of multiple equilibria may justify extensive policy experimentations to attempt a jump to a better equilibrium. If it is instead the same equilibrium that shifts, it becomes important to understand the precise drivers of this shift and perform some cost-benefit analysis when public investment is involved.

To answer the questions raised above, three main challenges need to be overcome. The first is to find a large temporary population shock. Our work exploits one of the largest inflows of refugees in modern times. About 1 million refugees were forced to leave Burundi in 1993 and Rwanda in 1994 to be hosted in the neighboring region of Kagera in Tanzania. All refugees from Rwanda were repatriated in 1996, and by 2004 most refugees from Burundi had moved back to their country of origin or relocated into a neighboring region.

The second challenge is to find appropriate data tracking the local population over a long period of time. By surveying exactly the same households between 1991 and 2010, the Kagera Health and Development Survey dataset provides the opportunity to assess the impact of refugees up to 14 years after the bulk of them were forced to repatriate.

The third main challenge is to develop a suitable estimation strategy. We argue and empirically show that such refugee inflows can be considered as a natural experiment. This characterization allows us to demonstrate the exogeneity of the economic improvements in the Kagera region even long after the refugees' departure. We then show that these improvements are best interpreted in the context of a lowering of trade costs following road construction to serve refugee camps. 
Our work contributes to the literature on the long-run effects of shocks and the identification of multiple equilibria. Since the seminal paper of Davis and Weinstein (2002), it has become common to exploit exogenous variation in bombing intensity in war episodes to investigate that issue (Brakman et al., 2004; Miguel and Roland, 2011). Those papers have tended to reject the existence of multiple equilibria, observing a return to pre-existing patterns of economic activity and population distribution (Brakman et al., 2004; Davis and Weinstein, 2002), poverty levels, population density, infrastructure, and human capital (Miguel and Roland, 2011). However, that there is a persistent equilibrium in some cases is not enough to dismiss the notion of multiple equilibria. An alternative approach is to investigate the path dependence resulting from historical events. Bleakley and Lin (2012) showed that even though the historical advantages linked to the proximity to portage sites have become obsolete over time, such a proximity has still contemporaneous consequences on the distribution of population and economic activity. This may suggest that there were initially multiple equilibria. Then, after one equilibrium was chosen it turned out to be extremely persistent. While this interpretation is interesting, the evidence is indirect.

In a different vein, Redding et al. (2011) claimed evidence for multiple equilibria by showing that the division of Germany and its reunification led to a shift in the location of the main airport hub. ${ }^{1}$ Showing a large change over a period of time is necessary, but not sufficient for multiple equilibria to play a role, since one also needs to prove that there was no change in the fundamentals underlying the perhaps unique equilibrium. We show that in the case of the Kagera region the large changes that occurred after the arrival of the refugees and persisted after their departure can be explained to a great extent by new roads built to serve the refugee camps.

Our work is also related to the literature on migration and refugees. The consequences of migration flows on labor market outcomes and ultimately on the welfare of individuals in hosting communities have been investigated mainly in developed countries (Card, 1990; Borjas, 1999; Angrist and Kugler, 2003; Ottaviano and Peri, 2012, Docquier et al., forthcoming, are prominent examples). In developing countries, the issue has been explored from the perspectives of the migrants (Rosenzweig, 2007; Beegle et al., 2011; Grogger and Hanson, 2011), their countries of origin (Adams and Page, 2005; Hanson, 2009), or the households directly linked to migrants (Woodruff and Zenteno, 2007; Yang, 2008). As reviewed by Ruiz and Vargas-Silva (2013), an emerging literature also seeks to assess quantitatively the consequences of

\footnotetext{
${ }^{1}$ Bosker et al. (2007) also focused on Germany and exploited bombing intensity during World War II. Their results indirectly supported the existence of multiple equilibria for the case of German city growth.
} 
forced migration on the host population (Alix-Garcia and Saah, 2010; Baez, 2011; Maystadt and Verwimp, 2014). However, much of that literature has focused on the short-run impact on the hosting economy. None of these papers addresses the hysteresis effect found in this paper. Sarvimaki (2011) is an exception. He underscored the role of agglomeration economies to explain the long-run impact of forced migrants on Finnish hosting areas. As far as we know, our paper is the only one dealing with the persistent impact of forced migration in a developing country.

Finally, our paper is part of a recent literature that explores the effects of transportation infrastructure following Storeygard (2011), Banerjee et al. (2012) Ghani et al. (2012), Jedwab and Moradi (2013), Baum-Snow et al. (2013), Jedwab et al. (2013), Faber (2014), and Donaldson (forthcoming) in developing countries or Baum-Snow (2007), Michael (2008), Duranton and Turner (2012) and Duranton et al. (2013) in developed countries. We also contribute to an earlier literature that assesses the welfare improvements of road accessibility using household data (Jacoby, 2000; Jacoby and Minten, 2009; Khandker et al., 2009). Our main innovation here is to use a panel of households to limit the possible biases caused by changes in the composition of population after the construction of the new infrastructure. Our interpretation of road construction as a "historical accident" also echoes Jedwab et al.'s (2013) use of the construction of the colonial railroad in Kenya as a natural experiment.

The paper is organized as follows. Section 2 describes how the massive refugee inflows of 1993 and 1994 may help to explain the shift of equilibria observed in the region of Kagera in Tanzania between 1991 and 2010. By distinguishing between two periods (1991-2004 and 1991-2010), Section 3 shows that the impact of hosting refugees does not fade away over time, indicating a persistent and positive impact on households' welfare. Section 4 investigates possible channels of transmission. Section 5 concludes.

\section{Background}

The Kagera region is a remote region in northwestern Tanzania of about 30,000 square kilometers. As shown by the map in Figure 1, the Kagera region is located between Lake Victoria, Uganda, Rwanda, and Burundi. It hosted about 1.5 million people in the early 1990s. Kagera is one of the poorest regions of the country in terms of annual income per capita with an average of 149,828 Tanzanian shillings (Tzs, that is, US\$166 in 2001), representing less than 65 percent of the annual income per capita of the country 
Figure 1: The Kagera region and the location of refugee camps

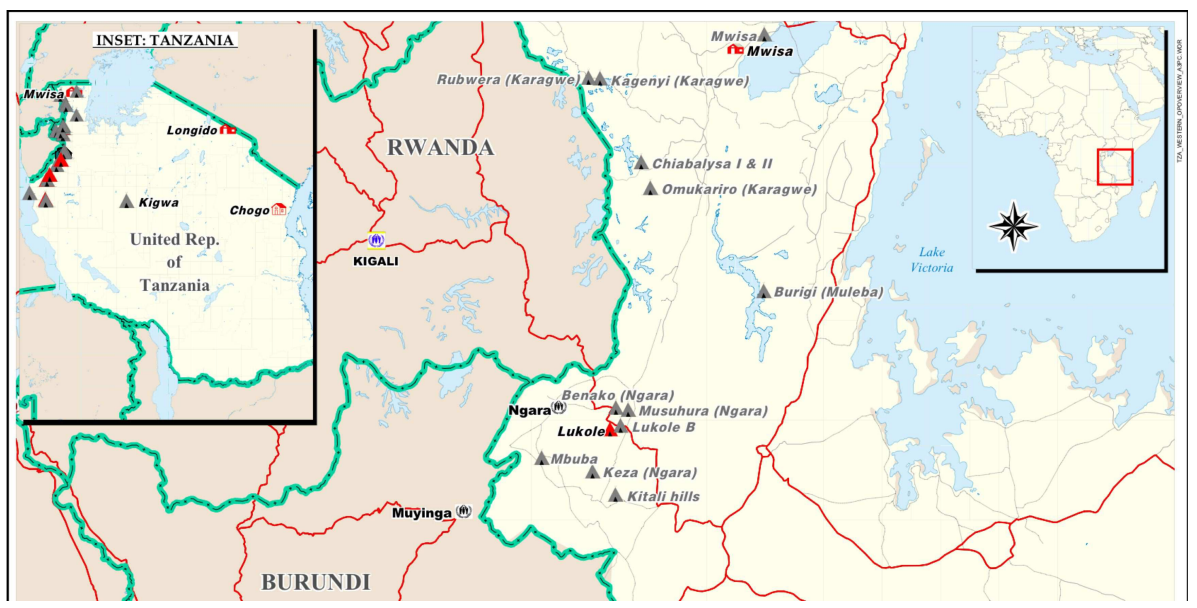

Source: UNHCR Regional Spatial Analysis Lab (Nairobi) and fieldwork geographic coordinates.

(Tanzania, NBS, 2003) .

Starting on October 21, 1993, between 250,000 and 300,000 Burundians fled into Tanzania following the assassination of the president of Burundi. A second influx of 250,000 refugees came from Rwanda over 24 hours on April 28, 1994 (Rutinwa, 2002), after the crash of the plane carrying the presidents of Rwanda and Burundi, which triggered the Rwandan genocide. This was largest and fastest exodus the UNHCR had ever witnessed. Over the next two months, it was followed by nearly another million refugees, fleeing Rwanda. In 1995, there remained about 800,000 refugees in Kagera. The majority, who originated from Rwanda, were forced to leave in 1996. Repatriation of the refugees from Burundi was more progressive. Their number continuously decreased to about 70,000 in 2004. The last camp (Lukole) was closed in June 2008.

The unanticipated and localized nature of the events provides a tool to isolate the impact of the refugee influx from other factors. As witnessed by a local aid worker, "They came very unexpectedly. The local population was never expecting such a thing. Just overnight, so many people were around. ... They came like a swarm of loco bees" (personal communication, May 6, 2008). Alix-Garcia and Saah (2010) also underlined the unexpected nature of the refugee flow following political assassinations.

Importantly, the influx of refugees in October-November 1993 was so sudden that refugees stayed close to local communities without formal assistance until April 1994. Their poor health conditions limited their ability to move very far away from where they originally crossed the border and, to protect 
them, borders had to be enforced by the military. The unexpected nature of the shock, together with the sheer number of refugees, prevented anyone, be it the Tanzanian government or UNHCR, from directing the refugees to the one or more locations across the region initially designated to host them. Instead, UNHCR and the Ministry of Home Affairs had to site a small number of city-sized camps within a very small radius of where the refugees had initially arrived. As can be seen in Figure 1, contrary to international law recommendations and to the guidelines of the UNHCR Handbookfor Emergencies, this siting resulted in camps located very close to the borders. ${ }^{2}$ That Tanzania was caught unprepared and had difficulty finding a place for hundreds of thousands of refugees removes, to a large extent, a potential problem of endogeneity. We discuss this issue further in Section 3. Furthermore, a new refugee policy implemented by the Tanzanian government restricted the movement of the refugees to 4 kilometers around the camps. These movement restrictions, coupled with geographical features limiting the spatial spread of the impact (Baez, 2011), provides an exceptional framework to identify the local effects of refugees.

According to people interviewed in the Kagera region, refugees are reported to have affected the local economy through various channels. ${ }^{3}$ First of all, the labor market was disrupted. While agricultural workers faced fiercer competition from refugees working in the fields, non-agricultural workers benefited from increased job opportunities provided by non-governmental organizations (the Red Cross, CARE, Tanganyika Christian Refugee Service, Norvegian People's Aid and so on) and UN agencies (UNHCR, World Food Programme). New varieties of goods (particularly non-food items) were introduced to meet international workers' different tastes. Farmers selling their products on the local market benefited from cheaper labor and higher crop prices. Agricultural production was reported to have doubled in some villages close to large refugee camps. Several businesses also mushroomed around the refugee camps. In turn, they attracted entrepreneurs from other regions. Second, upon the arrival of refugees, surging prices on the goods markets resulted from a new demand from the humanitarian sector and the refugees themselves (Alix-Garcia and Saah, 2010), while adverse health impacts were also documented (Baez, 2011). Environmental degradation and security concerns were also reported during the refugee crisis (Berry,

\footnotetext{
${ }^{2}$ Two exceptions appear on Figure 1: the camps of Burigi and of Mwisa. Both are special "protection camps" that were populated by only 10,000 refugees in 1995 , compared with 350,000 for the largest camp.

${ }^{3}$ Two months of iterative field research (Udry, 2003) fed the quantitative analysis presented in this paper. In order to refine some of our hypothesis, we conducted about 30 interviews, gathered data (notably refugee camp location and population), and collected some reports to better understand the economic environment of the region and the issues (management, interaction between refugees and local people) related to the refugee presence.
} 
2008). As we discuss below, the construction of refugees camps was also accompanied by significant infrastructure development.

\section{The Effect of Refugees}

\subsection{Data and Identification Strategy}

We use the Kagera Health and Development Survey (KHDS) dataset collected by Economic Development Initiatives and the World Bank (Beegle et al., 2006; De Weerdt et al., 2010). Based on the World Bank Living Standards Measurement Study standards (Grosh and Glewwe, 1995), KHDS provides comprehensive information on several dimensions of individual and household well-being, such as levels of consumption, income, and assets. It also documents some community and facilities characteristics, such as the availability of public services and so on.

Figure 2: Villages surveyed in the Kagera Health and Development Surveys

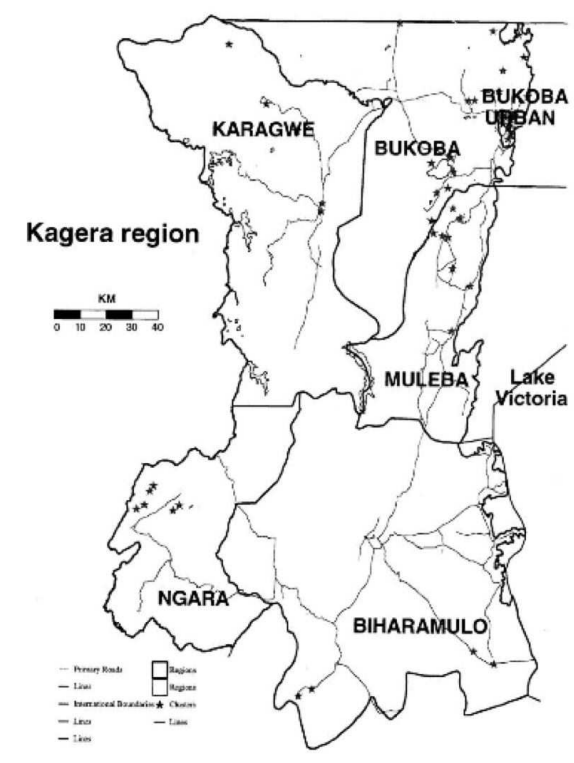

Source: Beegle et al. (2006)

In four waves, the KHDS interviewed 915 households and their members from fall 1991 to January 1994. Households originated from 51 randomly selected (with geographical stratification) Kagera communities (Figure 2). An important feature of this survey is that great efforts were made later to trace the whereabouts of individuals from the original 915 households. The field team achieved recontact rates 
above 90 percent about 10 and 16 years later, in 2004 and 2010. An important limitation of the 2010 data is that they do not contain information about income and village characteristics. Further description of the data can be found in Appendix A.

These data are particularly rich for assessing the impact of the refugee inflows of 1993-1994 on the local population. First, the first wave of the KHDS was undertaken before October 21, 1993, the date of the Burundi President's assassination and the start of the refugee crisis in the Kagera region. Therefore, the data should allow us to distinguish the effect of the refugee inflows from some initial differences between villages or households. Second, the location of the different villages throughout all the region allows us to introduce a key heterogeneity in our sample, depending on whether the households were living in a village close to a refugee camp or not. Third, we exploit waves 5 (2004) and 6 (2010) to assess the persistent nature of the temporary shock on the welfare of the local population.

By exploiting both time and spatial variations in the way households traced over time have been affected by the refugee inflows originating from Burundi (1993) and Rwanda (1994), we estimate the effect of the refugee presence, along with other explanatory variables defined at household or village level, on real consumption:

$$
\log \left(\frac{C_{h, t}}{P_{v(h, t), t}}\right)=\beta_{0}+\beta_{1} R I_{v(h, t), t}+\beta_{2} Z_{h, t}+\beta_{3} Q_{v(h, t), t}+\alpha_{t}+\alpha_{v(h, t)}+\alpha_{h}+\epsilon_{h, t}
$$

where $C_{h, t}$ denotes nominal consumption by household $h$ in year $t ; P_{v(h, t), t}$ is the price level in village $v$ in year $t$, where household $h$ lives during the same year; $R I_{v(h, t), t}$ is an index measure of refugee inflow; $Z_{h, t}$ are household characteristics; $Q_{v(h, t), t}$ are village characteristics; and $\alpha_{t}, \alpha_{v(h, t)}$, and $\alpha_{h}$ are time, location, and household fixed effects, respectively. We use robust standard errors, clustered at the initial village level, to account for correlation within villages (Moulton, 1986; Bertrand et al., 2004). ${ }^{4}$

Let us now discuss these variables in turn. Our dependent variable is defined as the real consumption per adult equivalent. Consumption data are only fully comparable for the years 1991, 2004, and 2010, so that we mainly use waves 1,5 , and 6 of the KHDS for our analysis. The adult equivalent transformation is applied using the method proposed by Collier et al. (1986) for Tanzania. More information about the construction of this variable is given in Appendix A. In our robustness checks, we also use alternative

\footnotetext{
${ }^{4}$ Similar results (even more efficient) are found when standard errors are instead corrected for spatial correlation based on the nonparametric covariance matrix estimator proposed by Driscoll and Kraay (1998).
} 
dependent variables such as the consumption of food and non-food items. To understand the channels through which these effects are working we also estimate regressions using price indexes as dependent variables.

The explanatory variable of interest measures the way each household was affected by the refugees in 1993-1994. To construct the refugee index we use information on both the population of refugee camps and the distance between the villages where households live and the refugee camps. The estimated number of refugees per camp in 1995, the peak of the refugee presence, was collected through fieldwork. More specifically, we sum the refugee population weighted by inverse distance: $\sum_{c=1}^{13} \frac{p o p_{c}}{d_{v, c}}$, where $c$ goes from 1 to 13 refugee camps and $v$ from 1 to 51 villages. The resulting variable is continuous, takes the value zero in 1991, and for the sake of assessing the persistent impact of the refugee presence is the same for 2004 and 2010. We then log this quantity (and add 1 to deal with the zero values in 1991) to obtain our refugee index, $R I_{v, t}$. Our decision to use a $\log$ is motivated by the fact that six villages appear to be particularly exposed to the refugee presence (with value equivalent to more than 20,000 refugees in the vicinity or 200,000 at an average distance of 10 kilometers). We refer to these six villages as "high-refugee areas." In the absence of strong priors about the exact functional form needed to measure refugee exposure, we explore a number of alternatives in our robustness checks.

Household characteristics include the age, its square, and the level of education of the head; a dummy indicating whether the household head has a chronic illness; dummies indicating the sex and marital status of the household head; the average education level of the household members; dummies for splitoff households (such as a child identified in 1991, who creates a new household by 2004 or by 2010); and the log of the size of the household.

We also construct climatic variables with monthly rainfall data in total millimeters, averaged over the growing periods of the last two years and transformed into anomalies. Appendix A provides more information about the construction of that variable. These data are available from the Tanzania Meteorological Agency for 1980 to 2010. In Section 4, we will also make use of other village-level data, based on the community questionnaire of the KHDS (distance to health services, secondary school, number of social services and non-governmental organizations, village population) or secondary data (road accessibility, distance to borders, and bilateral trade data). The construction of these variables is postponed to Section 4. 
Table 1: Descriptive statistics for main results (mean values)

\begin{tabular}{lccccccrc}
\hline & $\begin{array}{c}\text { Real } \\
\text { consumpt. (head) } \\
(2010 \text { Tzs) }\end{array}$ & $\begin{array}{c}\text { Age } \\
\text { (head) }\end{array}$ & & $\begin{array}{c}\text { Education Chronic } \\
\text { illness } \\
\text { (head) }\end{array}$ & $\begin{array}{c}\text { Size of } \\
\text { household household of household }\end{array}$ & $\begin{array}{c}\text { Split-year } \\
\text { average }\end{array}$ \\
\hline 1991 & & & & & & & Mean educ. Rainfall \\
High-refugee areas & 313,471 & 46 & 3.2 & 0.19 & 6.42 & - & 1.81 & 139.40 \\
Other areas & 437,320 & 49.2 & 4.4 & 0.20 & 7.58 & - & 2.25 & 161.75 \\
All & 424,579 & 48.8 & 4.3 & 0.18 & 7.47 & - & 2.21 & 159.53 \\
\hline \hline 2004 & & & & & & & & \\
High-refugee areas & 412,119 & 41.5 & 4.8 & 0.30 & 4.93 & 0.56 & 2.73 & 90.40 \\
Other areas & 613,367 & 44.2 & 5.7 & 0.27 & 5.29 & 0.58 & 3.76 & 144.83 \\
All & 592,995 & 43.9 & 5.6 & 0.27 & 5.26 & 0.58 & 3.65 & 139.40 \\
\hline \hline 2010 & & & & & & & & \\
High-refugee areas & 637,328 & 40.8 & 5.4 & 0.28 & 4.85 & 0.54 & 3.26 & 105.28 \\
Other areas & 837,775 & 41.4 & 6.7 & 0.20 & 4.53 & 0.62 & 4.59 & 117.03 \\
All & 817,797 & 41.3 & 6.5 & 0.21 & 4.56 & 0.61 & 4.46 & 115.86 \\
\hline
\end{tabular}

Notes: Real consumption is expressed in adult equivalent terms and in 2010 Tanzanian shillings (Tzs). Average monthly rainfall during the growing periods of the last two years is expressed in millimeters.

Table 1, which presents summary statistics, gives a first indication that high-refugee areas experienced an increase in real consumption per adult equivalent between 1991 and 2010. Refugee-hosting areas also differed from other areas in other respects. In particular, they appear to have been poorer, less educated, and less prone to rain-fed agriculture in 1991. These differences indicate that refugee camps were located in initially less favorable locations. Although political motivations, the health status, and the limited mobility of the refugees have been argued to reduce the potential selection of the most attractive locations for refugee camps, our summary statistics point at potentially negative selection, inasmuch as refugees happened to arrive in poorer areas. ${ }^{5}$ They also underscore the importance of location fixed effects and time-varying village characteristics in our estimating equation (1).

The initial differences found in the descriptive statistics of Table 1 also stress the importance of controlling for potential changes in the composition of groups by tracing exactly the same households and controlling for observed and unobserved characteristics. In particular, the household fixed effect, $\alpha_{h}$, controls for any unobserved permanent differences between households. The time dummy, $\alpha_{t}$, controls for

\footnotetext{
${ }^{5}$ That can also be shown by regressing the presence of refugees on all initial household and village characteristics, a village fixed effect and the initial real consumption per adult equivalent. The refugee presence is then negatively and significantly associated with the initial level of welfare. Similar results are obtained when the sample is restricted to households who were living in the two border areas, i.e. the districts of Karagwe and Ngara. Results are available in Table B.3 of Appendix B.
} 
time-varying events affecting all households.

The sample comprises 3,314 households, including households who had migrated within and outside of Kagera by 2004 and 2010. Due to missing consumption data, 414 households are excluded. Six households are excluded due to missing geographic coordinates and the resulting impossibility of linking them to weather data. The sample is reduced to 2,456 households when we exclude migrants. Including migrants allows us to introduce location fixed effects, $\alpha_{v(h)}$, along with household fixed effects. ${ }^{6}$ The sample of households followed between 1991 and 2004 includes 2,770 households, of which 155 households are dropped due to missing consumption data. Appendix A provides more detailed information on the construction of the sample. Our results are also shown to be robust to a change in the definition of the sample.

Including migrants in the sample has the advantage of accounting for native displacement. This matters because displaced natives are likely to form a selected subsample (Hatton and Tani, 2005; Card, 2005). As documented by Table A.2 in Appendix A, migration rates are markedly lower in high-refugee areas compared with other areas. However, a similar selection problem may occur because of attrition. Table A.2 in Appendix A reports lower attrition rates in high-refugee areas. This is unlikely to be an artefact of the data since the attrition rates for the whole sample closely match the rates provided by De Weerdt et al. (2010). These differences in attrition rates highlight the importance of household fixed effects, which allow us to focus on within-household variation.

\subsection{The Impact of Hosting Refugees}

Panels A and B of Table 2 report our main results regarding the effect of refugees over 1991-2004 and 1991-2010, respectively. In panel A, column 1 regresses real consumption per adult equivalent in 1991 and 2004 for all households in the KHDS data on the refugee index of their village, a time dummy, and a household fixed effect. The coefficient on the refugee index, which we can interpret, with a slight abuse of language, as an elasticity, is rather low, around 0.02. Column 2 adds location fixed effects to the specification of column 1. The coefficient on the refugee index increases to 0.03 and becomes close

\footnotetext{
${ }^{6}$ When estimated with household fixed effects, the location fixed effects capture the effect of moving from a household's initial location. A few households have migrated to another surveyed village. For the other households who have moved, we create new dummy variables if the household moves to one particular district in Kagera, to one particular region in Tanzania, or to Uganda. Although more aggregated, replacing the village dummy with an indicator that the household has migrated by 2004 and 2010 gives similar household fixed effect estimations, with even stronger evidence of the persistence of the impact.
} 
Table 2: Main results: Refugees and consumption

\begin{tabular}{|c|c|c|c|c|c|c|c|c|}
\hline \multirow{2}{*}{$\begin{array}{l}\text { Panel A } \\
\text { Dep. var. }\end{array}$} & (1) & $(2)$ & (3) & (4) & $(5)$ & $(6)$ & (7) & (8) \\
\hline & \multicolumn{8}{|c|}{ Real consumption per adult equivalent, 1991 and 2004} \\
\hline$R I_{v, t}$ & $\begin{array}{c}0.020 \\
(0.022)\end{array}$ & $\begin{array}{c}0.031 \\
(0.020)\end{array}$ & $\begin{array}{l}0.037^{*} \\
(0.020)\end{array}$ & $\begin{array}{c}0.049^{* *} \\
(0.019)\end{array}$ & $\begin{array}{c}0.020 \\
(0.019)\end{array}$ & $\begin{array}{c}0.030 \\
(0.021)\end{array}$ & $\begin{array}{l}0.032^{*} \\
(0.018)\end{array}$ & $\begin{array}{c}0.050^{* *} \\
(0.018)\end{array}$ \\
\hline$Z_{h, t}$ & No & No & No & No & Yes & Yes & Yes & Yes \\
\hline$Q_{v, t}$ & No & No & Yes & Yes & No & No & Yes & Yes \\
\hline$\alpha_{t}$ & Yes & Yes & Yes & Yes & Yes & Yes & Yes & Yes \\
\hline$\alpha_{v(h)}$ & No & Yes & No & Yes & No & Yes & No & Yes \\
\hline$\alpha_{h}$ & Yes & Yes & Yes & Yes & Yes & Yes & Yes & Yes \\
\hline Observations & 5,230 & 5,230 & 5,230 & 5,230 & 5,230 & 5,131 & 5,230 & 5,230 \\
\hline R-squared & 0.194 & 0.316 & 0.200 & 0.322 & 0.288 & 0.480 & 0.290 & 0.377 \\
\hline $\begin{array}{l}\text { Panel B } \\
\text { Dep. var. }\end{array}$ & \multicolumn{8}{|c|}{ Real consumption per adult equivalent, 1991 and 2010} \\
\hline$R I_{v, t}$ & $\begin{array}{c}0.012 \\
(0.040)\end{array}$ & $\begin{array}{c}0.064 \\
(0.040)\end{array}$ & $\begin{array}{c}0.017 \\
(0.040)\end{array}$ & $\begin{array}{l}0.085^{* *} \\
(0.037)\end{array}$ & $\begin{array}{l}0.081^{* *} \\
(0.034)\end{array}$ & $\begin{array}{c}0.115^{* * *} \\
(0.036)\end{array}$ & $\begin{array}{l}0.078^{* *} \\
(0.033)\end{array}$ & $\begin{array}{c}0.123^{* * *} \\
(0.035)\end{array}$ \\
\hline Observat & 5,788 & 5,788 & 5,788 & 5,788 & 5,788 & 5,788 & 5,788 & 5,788 \\
\hline R-squared & 0.356 & 0.453 & 0.357 & 0.454 & 0.454 & 0.508 & 0.454 & 0.509 \\
\hline
\end{tabular}

Notes: Robust standard errors clustered at the initial village level in parentheses. ${ }^{*},{ }^{* *},{ }^{* * *}$ : significant at $10 \%, 5 \%$, and $1 \%$, respectively. The same regressions are estimated in both panels. The sample includes all migrants.

to significant (with a p-value of 0.136). That increase is reassuring in light of potential selection into migration and similar issues regarding attrition. The location fixed effects are indeed estimated based on households that migrate from their baseline village, who represents about 30 percent of our observations. Column 3 adds time-varying location characteristics — that is, average monthly precipitation over the growing periods of the last two years - to the specification of column 1. The coefficient of the refugee index slightly increases. Together with the location fixed effects, the coefficient of the refugee index increases and becomes significant at a 95 percent level of confidence. This is of course in stark contrast with the fact that on average refugees arrived in areas that were initially much poorer than those that did not host refugees. At the same time, this is consistent with the summary statistics of Table 1 , which shows that real consumption per capita increased faster in high-refugee areas. Adding household characteristics to the specification in columns $5,6,7$, and 8 leaves previous estimates virtually unchanged. Estimated with location and household fixed effects and time-varying characteristics in column 8 , the coefficient of the refugee index remains significant and slightly increases, at 0.05 . That suggests a positive effect of 
refugees in 2004, 10 years after their arrival and 8 years after the departure of a large majority of them. ${ }^{7}$

Panel B of Table 2 replicates the specifications of panel A but uses 2010 household data instead of 2004 data. The impact of refugees, though a large majority have been gone for more than 10 years, is stronger, as soon as location fixed effects are introduced. The importance of introducing location fixed effects is illustrated by the increase in the coefficient in column 2. Nonetheless, the threats to identification seem to have evolved over time. Controlling for possible changes in the composition of households (in particular their average level of education) matters much more for the sample 1991-2010. That could be explained by changes in the returns on human capital at the times refugees were present in Kagera. The role of human capital accumulation is further discussed in Section 4. From panel B, it is clear that when fixed household characteristics are conditioned out, the impact of refugees is still observed in 2010, more than 10 years after most refugees left. The impact remains significant and between 0.08 and 0.12 .

Interestingly, such elasticity is of the same magnitude as the long-term impact (about 0.09) of population flows on wages found by Sarvimaki (2011) in the case of Finland. Adopting a general equilibrium perspective in the US context, Ottaviano and Peri (2012) found a much lower long-term average positive effect of immigration on native wages of about 0.6 percent. The comparability of migrants in the United States and refugees in Tanzania can obviously be called into question. But the difference of magnitude is puzzling enough to motivate further investigation on the channels of transmission in the next section.

Among the significant coefficients not reported in Table 2, we find strong negative effects for nonmarried heads of households and households having a head with a chronic illness, as should be expected. We also find a positive effect for split-off households. Split-off households are new households created as of 2004 and 2010 by previously surveyed household members. Given the multiplication of households over time, it is key to control for such changes in our comparison groups. We also find a coefficient of around $0.07-0.09$ for the average education of the household. This coefficient is typical of extant findings in the literature for apparent returns on education in Sub-Saharan Africa (Psacharopoulos, 1994; Schultz, 1999). A positive deviation in rainfall during the last two growing seasons has a positive impact on real

\footnotetext{
${ }^{7}$ This does not prevent negative effects around the time of their arrival, of course. Note that Maystadt and Verwimp (2014) found a higher coefficient of about 0.06-0.07. With our sample, a similar coefficient may be obtained by using their larger consumption basket in the definition of the real consumption per adult equivalent and introducing their additional time-varying village characteristics (reported natural and epidemic disasters). For comparability between our two samples, 1991-2004 and 1991-2010, we do not allow for these alternative specifications in Table 2, because these additional data are not available in the last round of the KHDS.
} 
consumption, as expected in an economy that largely depends on rain-fed agriculture (Beegle et al., 2011).

\subsection{Robustness Checks}

The above results rely on a number of identifying assumptions and specification choices. We therefore examine their robustness to (1) the existence of a pre-refugee trend; (2) the role of unobserved time-varying location characteristics; (3) changes in the sample of households followed over time; (4) alternative specifications of the dependent variable; and (5) alternative definitions of our main variable of interest, the refugee index.

Robustness to differential growth trends. We assume that households affected by the presence of refugees would have followed a similar trajectory in terms of real consumption per adult equivalent if refugees had not landed in Kagera. We can construct the same variables as above for an additional prerefugee year to conduct a "placebo" test and explore whether differences in outcomes can be explained by the "refugee presence" when refugees were not yet present. Based on the sample of households followed between 1991 and 1993, column 1 of panel A in Table 3 suggests that the positive effect of the refugee index on real consumption per adult equivalent cannot be explained by changes occurring before the refugees arrived. ${ }^{8}$ Adding household (column 2) and location (column 3) characteristics leave the coefficient virtually unchanged.

Nonetheless, the lack of significant coefficients may simply reflect the reduction of the sample to about 770 households followed between 1991 and 1993. We investigate this issue further by introducing future split-off households in the sample. Over-sampling those households whose members will be followed in a larger proportion by 2004 and 2010 confirms in columns 4 to 6 that our results may not be attributed to a trend existing before the refugees arrived. ${ }^{9}$ If there was a pre-refugee trend, it was rather a decreasing one. Nonetheless, columns 4-6 of Table 3 may indicate the risk of attributing to the presence of refugees the effects of a convergence process stronger in high-refugee areas compared with others. Panel B of Table 3

\footnotetext{
${ }^{8}$ We acknowledge that the comparison between 1991 and 1993 consumption data is not perfect because those data were collected based on different recall periods. Despite dividing the 1991 consumption data by 2 as suggested by Bengtsson (2010), we cannot exclude the existence of reporting errors due to different recall periods (Beegle et al., 2012). There is, however, no obvious reason to believe the measurement error introduced by such a difference of recall periods may be different between high-refugee areas and other areas.

${ }^{9}$ Over-sampling the future split-off households in panel A of Table 2 also gives similar point estimates.
} 
Table 3: Placebo test (parallel trend assumption)

\begin{tabular}{|c|c|c|c|c|c|c|}
\hline \multirow{3}{*}{$\begin{array}{l}\text { Sample } \\
\text { Panel A } \\
\text { Dep. var. }\end{array}$} & \multicolumn{3}{|c|}{ Balanced panel } & \multicolumn{3}{|c|}{$\begin{array}{l}\text { Including future split-off } \\
\text { households }\end{array}$} \\
\hline & (1) & $(2)$ & (3) & (4) & $(5)$ & (6) \\
\hline & \multicolumn{6}{|c|}{ Real consumption per adult equivalent, 1991 and 1993} \\
\hline False $R I_{v, t}$ & $\begin{array}{l}-0.002 \\
(0.013)\end{array}$ & $\begin{array}{l}-0.002 \\
(0.013)\end{array}$ & $\begin{array}{l}-0.006 \\
(0.014)\end{array}$ & $\begin{array}{l}-0.070 \\
(0.051)\end{array}$ & $\begin{array}{l}-0.082 \\
(0.049)\end{array}$ & $\begin{array}{l}-0.127^{* *} \\
(0.050)\end{array}$ \\
\hline$Z_{h, t}$ & No & Yes & Yes & No & Yes & Yes \\
\hline$Q_{v, t}$ & No & No & Yes & No & No & Yes \\
\hline$\alpha_{t}$ & Yes & Yes & Yes & Yes & Yes & Yes \\
\hline$\alpha_{h}$ & Yes & Yes & Yes & Yes & Yes & Yes \\
\hline Observations & 1,540 & 1,540 & 1,540 & 5,714 & 5,714 & 5,714 \\
\hline R-squared & 0.987 & 0.987 & 0.987 & 0.987 & 0.988 & 0.988 \\
\hline $\begin{array}{l}\text { Panel B } \\
\text { Dep. var. }\end{array}$ & \multicolumn{6}{|c|}{ Real consumption per adult equivalent, 1991 and 1993} \\
\hline False $R I_{v, t}$ & $\begin{array}{c}-0.647^{* * *} \\
(0.056)\end{array}$ & $\begin{array}{l}-0.655^{* * *} \\
(0.055)\end{array}$ & $\begin{array}{c}-0.653^{* * *} \\
(0.055)\end{array}$ & $\begin{array}{c}-0.663^{* * *} \\
(0.081)\end{array}$ & $\begin{array}{c}-0.668^{* * *} \\
(0.080)\end{array}$ & $\begin{array}{c}-0.668^{* * *} \\
(0.080)\end{array}$ \\
\hline $\begin{array}{l}\text { False } R I_{v, t} \\
\times \text { Initial cons } \text { I }_{v, 1991}\end{array}$ & $\begin{array}{c}0.083^{* * *} \\
(0.007)\end{array}$ & $\begin{array}{c}0.084^{* * *} \\
(0.007)\end{array}$ & $\begin{array}{c}0.084^{* * *} \\
(0.007)\end{array}$ & $\begin{array}{c}0.070^{* * *} \\
(0.008)\end{array}$ & $\begin{array}{c}0.069^{* * *} \\
(0.008)\end{array}$ & $\begin{array}{c}0.069^{* * *} \\
(0.008)\end{array}$ \\
\hline Observations & 1,540 & 1,540 & 1,540 & 5,714 & 5,714 & 5,714 \\
\hline R-squared & 0.989 & 0.990 & 0.990 & 0.989 & 0.990 & 0.990 \\
\hline
\end{tabular}

Notes: Robust standard errors clustered at the initial village level in parentheses. ${ }^{*},{ }^{* *},{ }^{* * *}$ : significant at $10 \%, 5 \%$, and $1 \%$, respectively. The same regressions are estimated in both panels.

augments the regressions presented in panel $\mathrm{A}$ with the interaction term between the presence of refugees and the initial real consumption averaged at the initial village level. Initially richer villages were actually growing faster compared with other villages within high-refugee areas. Such a pre-existing trend points to the lower-bound nature of our estimates.

Robustness to geography. We cannot be certain that our identification strategy is not picking up unobserved time-variant characteristics, somehow related to the presence of refugees. We know that refugee camps are strongly correlated with proximity to the borders. One concern may be that our variable of interest captures unobserved time-varying characteristics, related to the distance to the borders with Rwanda and Burundi. At the cost of removing relevant variation, equation (1) can be augmented with an interaction term between the distance to the border(s) and a time dummy. ${ }^{10}$ Panel B of Table 4 reports the

\footnotetext{
${ }^{10}$ That variable is actually used by Baez (2011) as a proxy for the refugee inflows in Kagera while assessing the impact on child health outcomes. We believe that the proposed refugee index is a less noisy measurement of the presence of refugees.
} 
coefficient of the refugee index in this augmented model. The detailed results are to be found in Table B.6 of Appendix B. We find that this augmented model provides even stronger results. At equal distance to the border, doubling the presence of refugees would increase real consumption per adult equivalent by 6 percent by 2004 and 21 percent by 2010. Given the location of the regional capital in the eastern part of Kagera, our results are also unlikely to be driven by a distinct trend in urban versus rural areas. The KHDS defines an urban community based on the assessment of the community leader in the first round of the survey. Panel $\mathrm{C}$ of Table 4 reports the coefficient of the refugee index when excluding urban areas. The detailed results are to be found in Table B.7 of Appendix B. As expected, the magnitude of the coefficient of interest increases when we exclude households living in urban areas.

Robustness to sample definition. The households moving from their initial village by 2004 or by 2010 are included in the sample of our main results. The rationale is to take into account possible native displacements that could bias the estimation of the impact of refugees on the population of interest. Nonetheless, one may argue that the positive impact of refugees on real consumption per adult equivalent may be inflated in case migrants from high-refugee areas would reap greater benefits (for unknown reasons) from migration compared with migrants from other areas, despite the fact that migration rates are much lower in high-refugee areas. We know that in the region of Kagera, migration out of the original village is associated with an improvement in real consumption of about 36 percent between 1991 and 2004 (Beegle et al., 2011). Those who migrated out of the region by 2010 became twice as rich as those who decided to stay (De Weerdt and Hirvonen, 2012). Panels D and E of Table 4 report the coefficient of interest, when excluding those households who have moved from their original village either within or outside Kagera. The detailed results are to be found in Tables B.8 and B.9 of Appendix B. We find even higher coefficients. That confirms that we are unlikely to capture the confounding effect of unobserved characteristics between migrants of high-refugee areas versus those of other areas. Our results are also robust to dropping one village at a time, rejecting the risk that one single outlier drives all the results. The minimum and maximum values of the coefficient of interest shown in panels $\mathrm{F}$ and $\mathrm{G}$ of Table 4 feature remarkable stability to that sensitivity test.

Robustness to the choice of dependent variables. Our results are robust to alternative dependent variables. In panels $\mathrm{H}$ and I of Table 4, we distinguish food and non-food real consumption per adult equiva- 
Table 4: Robustness to alternative samples and dependent variables (Summary)

Dep. var.

Real consumption per adult equivalent

Sample A: 1991 - 2004

(1)

(2)

(3)

Sample B: 1991 - 2010

\begin{tabular}{|c|c|c|c|c|c|c|}
\hline & (1) & (2) & (3) & (4) & (5) & (6) \\
\hline A. Main results & $\begin{array}{l}0.049^{* *} \\
(0.019)\end{array}$ & $\begin{array}{l}0.032^{*} \\
(0.018)\end{array}$ & $\begin{array}{c}0.050^{* * *} \\
(0.018)\end{array}$ & $\begin{array}{l}0.085^{* *} \\
(0.036)\end{array}$ & $\begin{array}{l}0.078^{* *} \\
(0.033)\end{array}$ & $\begin{array}{c}0.123^{* * *} \\
(0.035)\end{array}$ \\
\hline $\begin{array}{l}\text { B. Controlling for distance to } \\
\text { borders* } D_{t}\end{array}$ & $\begin{array}{c}0.062^{* * *} \\
(0.020)\end{array}$ & $\begin{array}{c}0.064^{* * *} \\
(0.019)\end{array}$ & $\begin{array}{c}0.056^{* * *} \\
(0.019)\end{array}$ & $\begin{array}{c}0.167 \\
(0.158)\end{array}$ & $\begin{array}{l}0.358^{* *} \\
(0.137)\end{array}$ & $\begin{array}{c}0.212 \\
(0.144)\end{array}$ \\
\hline C. Excluding urban areas & $\begin{array}{l}0.054^{* *} \\
(0.023)\end{array}$ & $\begin{array}{c}0.035 \\
(0.022)\end{array}$ & $\begin{array}{c}0.059^{* * *} \\
(0.022)\end{array}$ & $\begin{array}{l}0.106^{* *} \\
(0.041)\end{array}$ & $\begin{array}{l}0.087^{* *} \\
(0.036)\end{array}$ & $\begin{array}{c}0.140^{* * *} \\
(0.038)\end{array}$ \\
\hline $\begin{array}{l}\text { D. Excluding migrants } \\
\text { outside Kagera }\end{array}$ & $\begin{array}{c}0.053^{* * *} \\
(0.019)\end{array}$ & $\begin{array}{l}0.039^{* *} \\
(0.018)\end{array}$ & $\begin{array}{c}0.054^{* * *} \\
(0.018)\end{array}$ & $\begin{array}{l}0.079^{* *} \\
(0.039)\end{array}$ & $\begin{array}{c}0.121^{* * *} \\
(0.034)\end{array}$ & $\begin{array}{c}0.119^{* * *} \\
(0.035)\end{array}$ \\
\hline $\begin{array}{l}\text { E. Excluding movers } \\
\text { within and outside Kagera }\end{array}$ & & $\begin{array}{l}0.058^{* *} \\
(0.023)\end{array}$ & & & $\begin{array}{c}0.105^{* * *} \\
(0.039)\end{array}$ & \\
\hline $\begin{array}{l}\text { F. Minimum value from } \\
51 \text { regressions (dropping } 1 \text { village) }\end{array}$ & $\begin{array}{l}0.042^{* *} \\
(0.019)\end{array}$ & $\begin{array}{c}0.026 \\
(0.017)\end{array}$ & $\begin{array}{l}0.043^{* *} \\
(0.018)\end{array}$ & $\begin{array}{c}0.031 \\
(0.019)\end{array}$ & $\begin{array}{c}0.038 \\
(0.030)\end{array}$ & $\begin{array}{c}0.076^{* * *} \\
(0.024)\end{array}$ \\
\hline $\begin{array}{l}\text { G. Maximum value from } \\
51 \text { regressions (dropping } 1 \text { village) }\end{array}$ & $\begin{array}{c}0.054^{* * *} \\
(0.019)\end{array}$ & $\begin{array}{c}0.037^{* *} \\
(0.018)\end{array}$ & $\begin{array}{c}0.055^{* * *} \\
(0.018)\end{array}$ & $\begin{array}{l}0.091^{*} \\
(0.046)\end{array}$ & $\begin{array}{l}0.068^{* *} \\
(0.025)\end{array}$ & $\begin{array}{c}0.128^{* * *} \\
(0.042)\end{array}$ \\
\hline $\begin{array}{l}\text { H. Using food consumption } \\
\text { as dep. var. }\end{array}$ & $\begin{array}{l}0.035^{*} \\
(0.019)\end{array}$ & $\begin{array}{c}0.022 \\
(0.019)\end{array}$ & $\begin{array}{l}0.040^{* *} \\
(0.018)\end{array}$ & $\begin{array}{c}0.120^{* * *} \\
(0.044)\end{array}$ & $\begin{array}{l}0.091^{* *} \\
(0.034)\end{array}$ & $\begin{array}{c}0.144^{* * *} \\
(0.042)\end{array}$ \\
\hline $\begin{array}{l}\text { I. Using non-food consumption } \\
\text { as dep. var. }\end{array}$ & $\begin{array}{c}0.087^{* * *} \\
(0.025)\end{array}$ & $\begin{array}{c}0.067^{* * *} \\
(0.024)\end{array}$ & $\begin{array}{c}0.085^{* * *} \\
(0.024)\end{array}$ & $\begin{array}{c}0.084^{* * *} \\
(0.029)\end{array}$ & $\begin{array}{l}0.107^{* *} \\
(0.041)\end{array}$ & $\begin{array}{c}0.139^{* * *} \\
(0.032)\end{array}$ \\
\hline $\begin{array}{l}\text { J. Excluding self-produced } \\
\text { consumption from dep. var. }\end{array}$ & $\begin{array}{c}0.044^{* * *} \\
(0.021)\end{array}$ & $\begin{array}{c}0.029 \\
(0.020)\end{array}$ & $\begin{array}{l}0.045^{* *} \\
(0.020)\end{array}$ & $\begin{array}{l}0.081^{* *} \\
(0.035)\end{array}$ & $\begin{array}{l}0.072^{* *} \\
(0.033)\end{array}$ & $\begin{array}{c}0.120^{* * *} \\
(0.035)\end{array}$ \\
\hline$Z_{h, t}$ & No & Yes & Yes & No & Yes & Yes \\
\hline$Q_{v, t}$ & Yes & Yes & Yes & Yes & Yes & Yes \\
\hline$\alpha_{t}$ & Yes & Yes & Yes & Yes & Yes & Yes \\
\hline$\alpha_{v(h)}$ & Yes & No & Yes & Yes & No & Yes \\
\hline$\alpha_{h}$ & Yes & Yes & Yes & Yes & Yes & Yes \\
\hline
\end{tabular}

Notes: Only the coefficient for $R I_{v, t}$ is reported. Robust standard errors clustered at the initial village level in parentheses. ${ }^{*},{ }^{* *},{ }^{* *}$ : significant at $10 \%, 5 \%$, and $1 \%$, respectively. The same regressions are estimated in both samples. 
lent. The detailed results are to be found in Table B.10 of Appendix B. In panels H and I of Table 4, larger coefficients of interest are found for non-food real consumption, perhaps as a result of non-homothetic preferences. We also replicate our main results excluding self-produced consumption. Such consumption is usually underestimated in household surveys. Given the possible exit out of subsistence agriculture into market-based activities in high-refugee areas compared with other areas, such a measurement error may introduce an upward bias in the estimated impact of the refugee presence on total consumption. In panel $\mathrm{J}$ of Table 4, our results are virtually unchanged when self-produced consumption is excluded.

Robustness to the refugee index. Our results are robust to alternative definitions of the treatment variable. In particular we now generalize our refugee index to $\sum_{c=1}^{13} \frac{p o p_{c}}{d_{v, c}^{\gamma}}$ with $\gamma$ equal to $0.5,2$, or 3 . We standardize the variable of interest in order to be able to compare the magnitude of the coefficients. Panels A to $\mathrm{D}$ of Table 5 indicate that the larger $\gamma$ is - that is, the sharper the decay function -, the smaller the coefficient of interest is. The detailed results are to be found in Table B.11 of Appendix B. In panels E and $\mathrm{F}$ of Table 5, our results are also robust to restricting the construction of the refugee index to refugees from Rwanda or from Burundi. These refugees were indeed hosted in different refugee camps. We find that the impact of the refugees from Rwanda on the welfare of the hosting population is even stronger than that of those from Burundi. Economically, doubling the presence of refugees from Rwanda increases the welfare of the hosts by 8 percent by 2004 and 14 percent by 2010, even if refugees from Rwanda were forced to repatriate in 1996. The persistence of the welfare impact of hosting refugees is therefore further established. Our results are in a similar range when we exclude one refugee camp at a time, rejecting the risk that a single refugee camp is driving the results. The minimum and maximum values of the coefficient of interest are reported in panels $\mathrm{G}$ and $\mathrm{H}$ of Table 5. Furthermore, the logarithm transformation is not necessarily neutral. However, panel I of Table 5 confirms our main results, with a slightly different interpretation. An increase of about 100,000 refugees at 6.12 kilometers (the closest distance between the surveyed villages and any refugee camp) would give an increase in real consumption per adult equivalent by about 6 percent by 2004 and 15 percent by $2010 .{ }^{11}$ Finally, we also use an alternative treatment based

\footnotetext{
${ }^{11}$ Because it is not easy to compare the effects of the refugee index across specifications, we consider the same increase of 100,000 refugees at 6.12 kilometers. By the estimations of column (3) of Table 5, this implies a slightly lower increase in real consumption per adult equivalent of about 2-3 percent by 2004, when proximity is assumed to matter more $(\gamma=2, \gamma=3)$. The same refugee increase translates into a rise of about 10 and 5 percent, when refugees are restricted to those coming from Rwanda and Burundi, respectively. By 2010, similar differences are found. Compared with a resulting increase by 15 percent without distinguishing the refugees based on their country of origin, an arrival of 100,000 refugees at 6.12 kilometers from
} 
Table 5: Robustness to alternative refugee index (summary)

Dep. var.

Real consumption per adult equivalent

Sample A: 1991-2004

(1)

(2)

(3)

Sample B: 1991-2010

\begin{tabular}{|c|c|c|c|c|c|c|}
\hline & (1) & (2) & (3) & (4) & (5) & (6) \\
\hline A. $R I_{v, t}$ with $\gamma=1$ & $\begin{array}{l}0.049^{* *} \\
(0.019)\end{array}$ & $\begin{array}{l}0.032^{*} \\
(0.018)\end{array}$ & $\begin{array}{c}0.050^{* * *} \\
(0.018)\end{array}$ & $\begin{array}{l}0.085^{* *} \\
(0.037)\end{array}$ & $\begin{array}{l}0.078^{* *} \\
(0.033)\end{array}$ & $\begin{array}{c}0.123^{* * *} \\
(0.035)\end{array}$ \\
\hline B. $R I_{v, t}$ with $\gamma=0.5$ & $\begin{array}{l}0.411^{* *} \\
(0.159)\end{array}$ & $\begin{array}{l}0.246^{*} \\
(0.152)\end{array}$ & $\begin{array}{c}0.423^{* * *} \\
(0.149)\end{array}$ & $\begin{array}{l}0.618^{* *} \\
(0.273)\end{array}$ & $\begin{array}{l}0.549^{* *} \\
(0.249)\end{array}$ & $\begin{array}{c}0.894^{* * *} \\
(0.251)\end{array}$ \\
\hline C. $R I_{v, t}$ with $\gamma=2$ & $\begin{array}{c}0.028^{* *} \\
(0.012)\end{array}$ & $\begin{array}{l}0.022^{* *} \\
(0.011)\end{array}$ & $\begin{array}{l}0.026^{* *} \\
(0.010)\end{array}$ & $\begin{array}{c}0.017 \\
(0.011)\end{array}$ & $\begin{array}{l}0.021^{*} \\
(0.011)\end{array}$ & $\begin{array}{c}0.028^{* *} \\
(0.013)\end{array}$ \\
\hline D. $R I_{v, t}$ with $\gamma=3$ & $\begin{array}{l}0.025^{* *} \\
(0.012)\end{array}$ & $\begin{array}{l}0.020^{*} \\
(0.011)\end{array}$ & $\begin{array}{l}0.023^{* *} \\
(0.010)\end{array}$ & $\begin{array}{c}0.010 \\
(0.006)\end{array}$ & $\begin{array}{l}0.013^{*} \\
(0.008)\end{array}$ & $\begin{array}{l}0.018^{*} \\
(0.009)\end{array}$ \\
\hline $\begin{array}{l}\text { E. } R I_{v, t} \text {, with refugees only } \\
\text { from Rwanda }\end{array}$ & $\begin{array}{l}0.082^{* * *} \\
(0.029)\end{array}$ & $\begin{array}{l}0.053^{*} \\
(0.028)\end{array}$ & $\begin{array}{c}0.083^{* * *} \\
(0.028)\end{array}$ & $\begin{array}{l}0.107^{* *} \\
(0.044)\end{array}$ & $\begin{array}{l}0.081^{*} \\
(0.044)\end{array}$ & $\begin{array}{c}0.138^{* * *} \\
(0.043)\end{array}$ \\
\hline $\begin{array}{l}\text { F. } R I_{v, t} \text {, with refugees only } \\
\text { from Burundi }\end{array}$ & $\begin{array}{l}0.043^{* *} \\
(0.018)\end{array}$ & $\begin{array}{c}0.028 \\
(0.017)\end{array}$ & $\begin{array}{l}0.044^{* *} \\
(0.016)\end{array}$ & $\begin{array}{l}0.045^{*} \\
(0.022)\end{array}$ & $\begin{array}{l}0.051^{* * *} \\
(0.019)\end{array}$ & $\begin{array}{c}0.072^{* * *} \\
(0.020)\end{array}$ \\
\hline $\begin{array}{l}\text { G. Minimum value from } \\
13 \text { regressions (dropping } 1 \text { refugee camp) }\end{array}$ & $\begin{array}{l}0.054^{* *} \\
(0.022)\end{array}$ & $\begin{array}{c}0.037 \\
(0.022)\end{array}$ & $\begin{array}{c}0.055^{* * *} \\
(0.020)\end{array}$ & $\begin{array}{l}0.073^{* *} \\
(0.034)\end{array}$ & $\begin{array}{c}0.077^{* *} \\
(0.033)\end{array}$ & $\begin{array}{c}0.110^{* * *} \\
(0.031)\end{array}$ \\
\hline $\begin{array}{l}\text { H. Maximum value from } \\
13 \text { regressions (dropping } 1 \text { refugee camp) }\end{array}$ & $\begin{array}{l}0.078^{* *} \\
(0.032)\end{array}$ & $\begin{array}{l}0.042^{*} \\
(0.023)\end{array}$ & $\begin{array}{c}0.082^{* * *} \\
(0.030)\end{array}$ & $\begin{array}{l}0.109^{* *} \\
(0.045)\end{array}$ & $\begin{array}{l}0.089^{* *} \\
(0.042)\end{array}$ & $\begin{array}{c}0.127^{* * *} \\
(0.036)\end{array}$ \\
\hline I. $R I_{v, t}$ without $\log$ & $\begin{array}{l}0.002^{* *} \\
(0.001)\end{array}$ & $\begin{array}{l}0.002^{* *} \\
(0.001)\end{array}$ & $\begin{array}{c}0.002^{* * *} \\
(0.001)\end{array}$ & $\begin{array}{l}0.005^{* *} \\
(0.002)\end{array}$ & $\begin{array}{c}0.005^{* * *} \\
(0.002)\end{array}$ & $\begin{array}{c}0.007^{* * *} \\
(0.002)\end{array}$ \\
\hline $\begin{array}{l}\text { J. Dummy for } \\
\text { high-refugee area* } D_{t}\end{array}$ & $\begin{array}{c}0.095 \\
(0.066) \\
\end{array}$ & $\begin{array}{c}0.040 \\
(0.054) \\
\end{array}$ & $\begin{array}{l}0.125^{*} \\
(0.062) \\
\end{array}$ & $\begin{array}{l}0.153^{* *} \\
(0.060)\end{array}$ & $\begin{array}{c}0.180^{* * *} \\
(0.047)\end{array}$ & $\begin{array}{c}0.216^{* * *} \\
(0.052) \\
\end{array}$ \\
\hline$Z_{h, t}$ & No & Yes & Yes & No & Yes & Yes \\
\hline$Q_{v, t}$ & Yes & Yes & Yes & Yes & Yes & Yes \\
\hline$\alpha_{t}$ & Yes & Yes & Yes & Yes & Yes & Yes \\
\hline$\alpha_{v(h)}$ & Yes & No & Yes & Yes & No & Yes \\
\hline$\alpha_{h}$ & Yes & Yes & Yes & Yes & Yes & Yes \\
\hline
\end{tabular}

Notes: Only the coefficient for $R I_{v, t}$ is reported. Most coefficients are standardized to ease comparison. No standardization is applied for panels I and J. Robust standard errors clustered at the initial village level in parentheses. ${ }^{*},{ }^{* *},{ }^{* * *}$ : significant at $10 \%, 5 \%$, and $1 \%$, respectively. The same regressions are estimated in both samples.

on a dummy variable indicating whether the household belongs to the six villages most impacted by the presence of refugees. As indicated in panel $\mathbf{J}$ of Table 5, such an alternative treatment variable would a village would translate into an improvement in real consumption per adult equivalent by 17 and 9 percent by 2010 , when refugees are restricted to those coming from Rwanda and Burundi, respectively. 
strongly increase the magnitude of the coefficient to about 12 percent by 2004 and 22 percent in 2010 . All detailed results are to be found in Table B.12 of Appendix B.

\section{Investigating the Possible Channels of Transmission}

\subsection{Theoretical Framework}

Our results so far document a sizable increase in welfare (measured in terms of real consumption) for villages more exposed to refugees long after these refugees have returned to their home country. The presence of refugees had a positive and persistent impact on the hosting economy. The effect did not fade away over time. On the contrary, the impact became stronger between 2004 and 2010.

The first and most standard interpretation for this finding would be a shift in the unique equilibrium. To illustrate this, panel A of Figure 3 proposes a simple demand and supply framework. The horizontal axis measures a quantity that we can loosely refer to as labor effort, which combines both the quantity and the intensity of labor supplied. Labor supply increases with labor income. This could be the result of workers' choosing to work more and have less leisure when the returns on labor increase. Alternatively, in a development context one may imagine that higher returns on labor allow workers to feed themselves better and subsequently supply more labor (Strauss and Thomas, 1998, 2008). The demand for labor is sloping downward as marginal returns on labor decrease when more labor is supplied. There is a unique initial equilibrium in $E_{0}$ for $\left(L_{0}, I_{0}\right)$. For a different level of income, such as $\left(L_{1}, I_{1}\right)$, to persist after the departure of refugees, either the demand curve or the supply curve must permanently shift. Hence, the temporary refugee shock cannot be in itself an explanation for this permanent change. While one may imagine a shift in the supply of labor following, for instance, refugees' transmitting a different work ethic or skills to the local population, an upward shift in the demand for labor following an increase in productivity is more plausible. The issue is then to identify the factor (or set of factors) that underlies this shift in productivity / labor demand and leads to the new equilibrium in $E_{1}$.

There is another possible interpretation behind the change from $E_{0}$ with $\left(L_{0}, I_{0}\right)$ to $E_{1}$ with $\left(L_{1}, I_{1}\right)$. While the supply curve may continue to slope upward, the labor demand curve may not be monotonic. Several possibilities can be envisioned to explain this. For instance, there might be a population threshold above which more productive interactions between workers may take place. These interactions are often 
Figure 3: Shifting equilibrium versus multiple equilibria
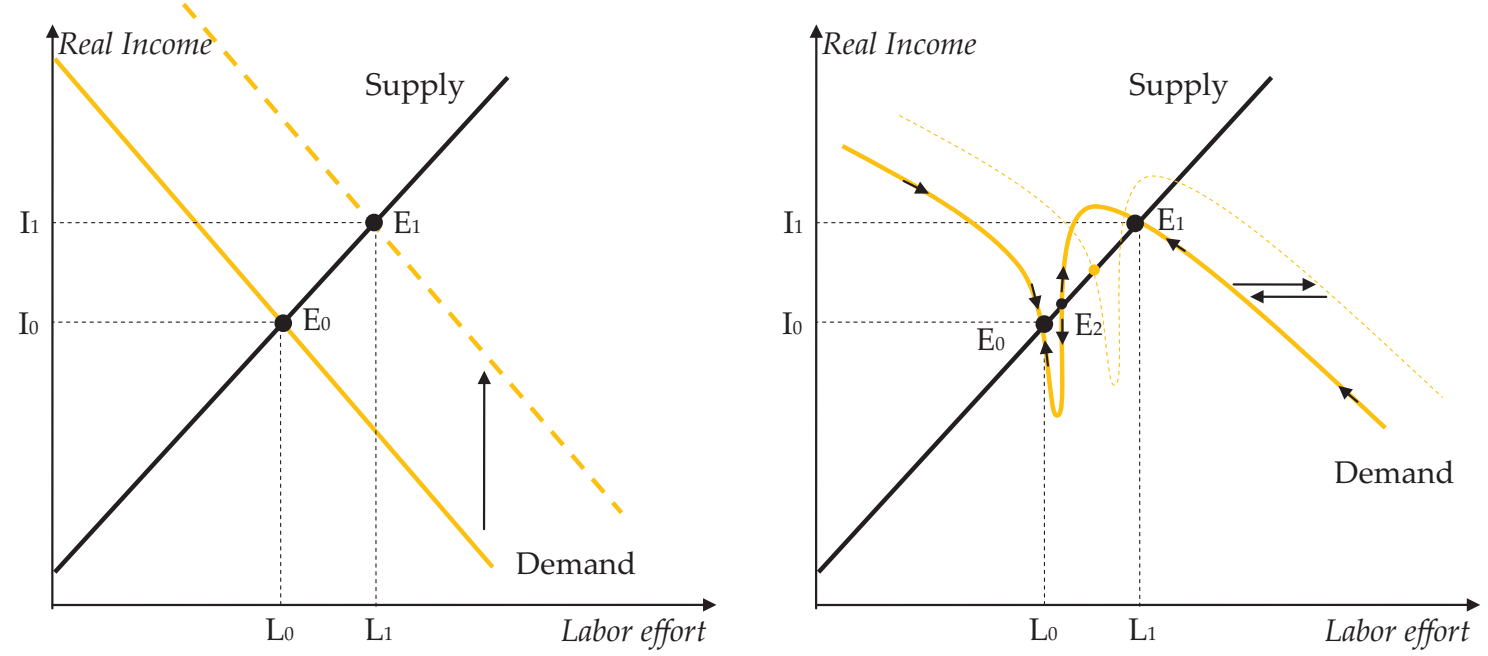

Panel A

Shift of equilibrium
Panel B

Multiple equilibria

referred to as agglomeration economies (Fujita and Thisse, 2002; Duranton and Puga, 2004). Alternatively, one may envision some non-monotonicity in the demand for products. Following Murphy et al. (1989), richer households may demand different goods produced under increasing returns to scale. In a similar vein, households below a given poverty threshold may be unable to save and face imperfect credit markets, preventing them from investing in more highly productive technologies (Azariadis and Drazen, 1990; Miguel and Roland, 2011). In panel (b) of Figure 3, we illustrate a case like this in which demand and supply intersect three times. The first intersection is in $E_{0}$. This is a stable equilibrium in the sense 
that following a small perturbation, the economy has a tendency to return to this equilibrium. There is a second stable equilibrium in $E_{1}$, which entails a higher level of labor effort and a higher income. There is also a third equilibrium in $E_{2}$. This equilibrium is unstable because a small perturbation away from it is self-reinforcing and will lead the economy to either $E_{0}$ or $E_{1}$.

Initially the economy may have been in $E_{0}$. The arrival of the refugees arguably represented a large shock in the demand for labor. The labor demand curve may have shifted temporarily to the right, as represented by the dashed curve. The equilibrium $E_{0}$ then moves temporarily with labor demand. The key point is that when labor demand returns to its initial level following the return of the refugees, the temporary equilibrium is now in the "basin of attraction" of $E_{1}$. Hence, instead of reverting to $E_{0}$, the economy shifts to the higher equilibrium in $E_{1}$. For this to be possible, the temporary shock associated with the influx of refugees needs to be large enough, which is empirically plausible.

Our stylized theoretical framework indicates that finding a positive and persistent impact of refugees on the welfare of the hosting population is not enough to draw any conclusion on the existence of multiple equilibria. The existence of multiple equilibria, due to agglomeration economies, non-homothetic preferences, or the break-up of a poverty trap, should be assessed against an alternative hypothesis, a shift of equilibrium resulting from subsequent infrastructure investments and changes in local fundamentals.

\subsection{Reduced Transport Costs as a Shifter of Equilibrium}

Following our fieldwork and in line with the above theoretical framework, one of the hypothesized channels through which refugees had a positive impact is investment in road infrastructure undertaken by UNHCR and the World Food Programme (WFP). Whitaker noted that "In Kagera region, more than 15 million dollars went towards the rehabilitation of main and feeder roads, airstrips, and telecommunications infrastructure," making “internal transportation cheaper and easier for host communities”(1999, 12). This might be very important in a region where the remoteness is an important determinant of the likelihood of growing out of poverty (De Weerdt, 2006). The literature has also provided important evidence on the ability of road infrastructure in particular to foster broad-based economic development (Jacoby, 2000; Jacoby and Minten, 2009; Khandker et al., 2009). Improved road accessibility, associated with the inflows of refugees, would be supportive of a shift of equilibrium, as opposed to strong evidence for multiple equilibria. 


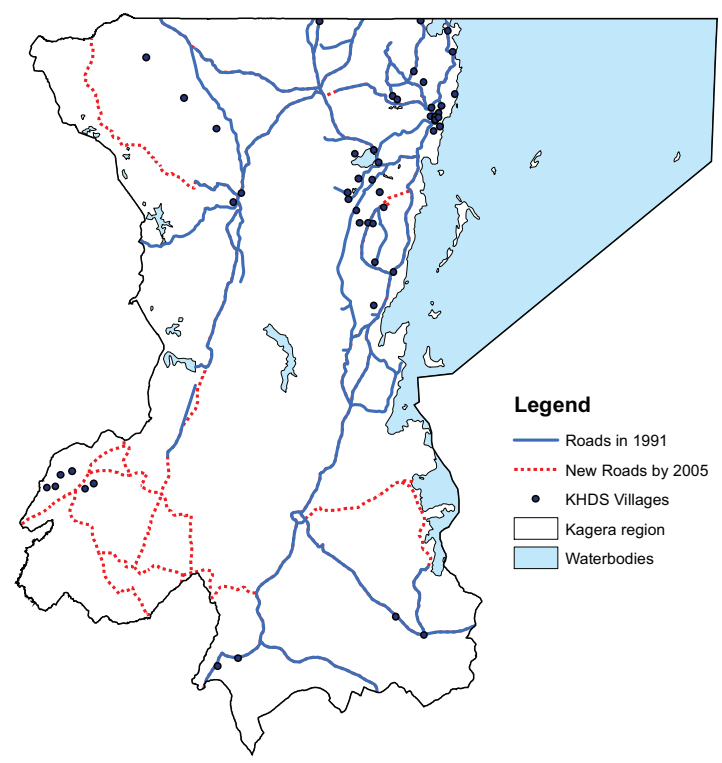

Source: Road networks from DIVA-GIS and the Tanzanian National Roads Agency. Note: KHDS = Kagera Health Development Survey

We measure road accessibility using the road network in 1991 and in 2005 (see Figure 4). The data sources are provided in Appendix A. We can measure road accessibility as the shortest distance between each village and the road network. An alternative is to construct buffers around each village with 20-, 15-, 10- or 5-kilometer radius and measure the length of the road segments within each buffer. Descriptive statistics, given in Table 6, indicate strong improvements in road accessibility in high-refugee areas.

As shown in Table 7, the presence of refugees has a positive and significant impact on road accessibility, measured in various ways. In columns 1 and 2 of panel A, we regress the length of roads within a buffer of 20 kilometers around each village on the presence of refugees, including or excluding timevarying village characteristics. Doubling the presence of refugees increases road accessibility by a factor 
Table 6: Descriptive statistics for village-level variables (mean values)

\begin{tabular}{|c|c|c|c|c|c|c|}
\hline & $\begin{array}{c}\text { Refugee index } \\
\text { no log }\end{array}$ & $\begin{array}{l}\text { Rainfall } \\
\text { average }\end{array}$ & $\begin{array}{c}\text { Distance } \\
\text { to road }\end{array}$ & $\begin{array}{c}\text { Access } \\
\text { within } 20 \mathrm{~km}\end{array}$ & $\begin{array}{c}\text { Access } \\
\text { within } 10 \mathrm{~km}\end{array}$ & $\begin{array}{c}\text { Access } \\
\text { within } 5 \mathrm{~km}\end{array}$ \\
\hline \multicolumn{7}{|l|}{1991} \\
\hline High-refugee areas & 0 & 139.4 & 38.0 & 0 & 0 & 0 \\
\hline Other areas & 0 & 161.75 & 1.59 & 119.0 & 41.8 & 15.0 \\
\hline All & 0 & 159.53 & 5.87 & 105.0 & 36.9 & 13.2 \\
\hline \multicolumn{7}{|l|}{2004} \\
\hline High-refugee areas & 34,550 & 90.40 & 7.10 & 104.2 & 36.9 & 7.8 \\
\hline Other areas & 6,040 & 144.83 & 3.13 & 108.0 & 36.4 & 14.2 \\
\hline All & 8,880 & 139.40 & 3.59 & 107.6 & 36.5 & 13.5 \\
\hline \multicolumn{7}{|l|}{2010} \\
\hline High-refugee areas & 34,550 & 105.28 & & & & \\
\hline Other areas & 6,040 & 117.03 & & & & \\
\hline All & 8,880 & 115.86 & & & & \\
\hline
\end{tabular}

Notes: Average monthly rainfall in millimeters during the growing periods of the last two years. Distance to roads or the lengths of roads are expressed in kilometers.

of 5.4 to $7.9 .^{12}$

This impact slightly decreases when the buffer is defined with a radius of 15 and 10 kilometers and decreases even further with a radius of 5 kilometers. Such a decrease reflects the lower ability to capture new road construction when the buffer is narrowly defined, because villages are not necessarily directly connected to the road networks. The impact decreases on average by about 71 percent when the roads that have been rehabilitated (independently from the presence of refugees) by the Tanzanian government are excluded from the road networks.

The road networks can also be used to identify six new road segments. In panels $\mathrm{C}$ and $\mathrm{D}$, we replicate the previous regressions of panels A and B, replacing the village fixed effects with the road fixed effects. This alternative provides a better control for unobserved factors affecting the endogenous location of new roads. Basically, we compare the effect of the presence of refugees on road accessibility among villages sharing the same new road segment. Panels C and D provide slightly lower coefficients, but the impact of doubling the presence of refugees remains in a similar range. It is hardly deniable that the impact is

\footnotetext{
${ }^{12}$ Given the lack of accuracy of the Taylor approximation for large values of quasi-elasticities, the value of 5.4 corresponds to an increase in road accessibility from a level A1 $(\ln A 1=2.4 \ln (R I))$ to a level A2 $(\ln A 2=2.4 \ln (2 * R I))$. Mathematically, applying basic rules for logarithmic transformations, one can show that $\ln A 2=2.4 \ln (2)+2.4 \ln (R I)=2.4 \ln (2)+\ln (A 1)$, which implies that $A 2 / A 1=\exp (2.4 \ln 2)=2^{2.44}=5.4$. The remaining interpretations of coefficients presented in Table 7 are computed in a similar way.
} 
Table 7: Assessing the role of road accessibility

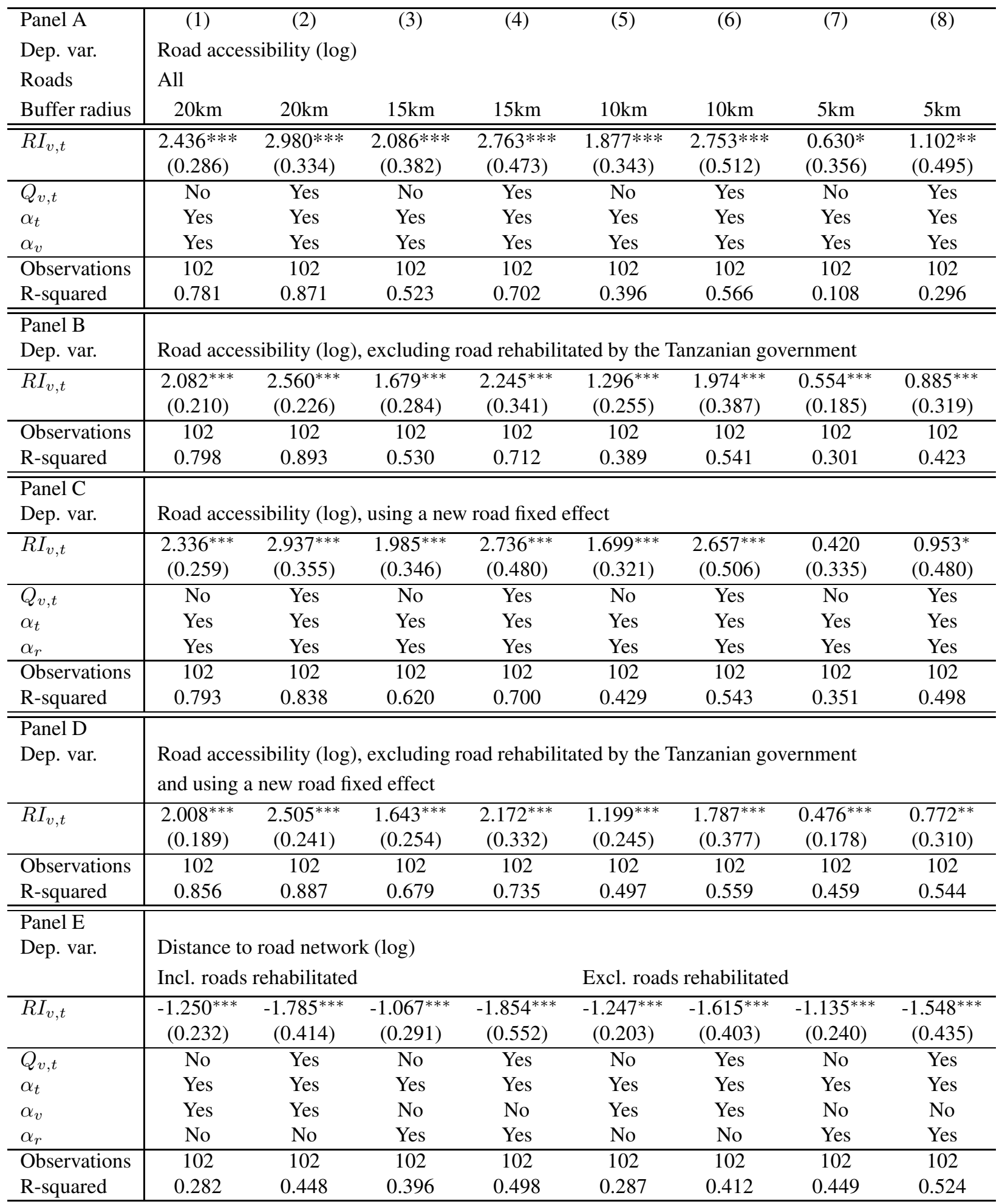

Notes: Robust standard errors in parentheses. ${ }^{*},{ }^{* *},{ }^{* * *}$ : significant at $10 \%, 5 \%$, and $1 \%$, respectively. The same regressions are estimated in all panels. $Q_{v, t}$ includes not only the rainfall anomalies but also the individual and household characteristics aggregated at the initial village level. 
economically large. But such an increase is coming from a particularly low level of road accessibility. A less sophisticated — but easier to interpret — approach is to introduce the closest distance to the road network. As indicated in panel E, doubling the presence of refugees decreases the distance to the closest road network in a range between 27 and 48 percent $\left(\left(2^{\text {elasticity }}\right) \times 100\right)$. In high-refugee areas (where average distance to the road was about 38 kilometers in 1991), that is equivalent to moving the road closer by 11-19 kilometers.

All in all, the drastic decrease in transport costs mainly induced by massive transport investment by international organizations (WFP and UNHCR) is strongly associated with the persistent welfare improvement observed in high-refugee areas. While it is impossible to fully refute the notion that roads may be endogenous to economic development, the institutional context of our analysis suggests that these roads were built to serve refugee camps. Given UNHCR guidelines that require refugee camps to be well connected and given the large scale of the refugee flows in Tanzania, UNHCR and the Tanzanian Ministry of Home Affairs had to build roads to serve refugee camps. ${ }^{13}$

The size of these effects is also consistent with road accessibility's being the main driver of the persistent impact of the refugee presence on the real consumption of the hosting population. In panel A of Table B.15 in Appendix B, we give some perspective to our main results by regressing the elasticity of consumption to roads. Using either a buffer of 20 kilometers or the distance to the road network, the road channel seems to account for more than 80 percent of the impact of the refugee presence on real consumption per adult equivalent by 2010. That proportion goes down to about 70, 55, and 37 percent when we use a smaller buffer of 15, 10 and 5 kilometers respectively to construct our measure of road

\footnotetext{
${ }^{13}$ A legitimate concern may be that refugee camps were located in easy-to-access areas to ease the provision of goods. For instance, the largest refugee camp, Benaco, took the name of an earlier Italian company that builds a road from Rusomo to Lusahunga between 1977 and 1985. At the time the refugees entered Kagera, the setup of the Benaco camp was reported to be eased by the presence of an Italian/Tanzanian road construction company, called Cogefar. After some works of port rehabilitation in the the islands of Zanzibar and Pemba from 1988 to 1992, Cogefar was then contracted in 1993 to build a road between Kobero (at the border with Rwanda) and Nyazkasanza (in Ngara district) in the region of Kagera ( $h t t p$ : //baldi.diplomacy.edu/italy/Italians/ittz5.htm). The contract of the company was immediately altered by the UNHCR to establish roads on the Benaco site (Tanzanian Affairs, 1994, http : //www.tzaffairs/1994/09/benaco - tanzanias second - city/). The presence of the company in Kagera certainly eased the establishment of new roads to provide food to refugee camps. That should be kept in mind while discussing the generalizable nature of our results (Section 5). However, it does not support the claim that refugee camps were located in areas with good road accessibility prior to the arrival of refugees. Regressing the presence of refugees on initial road accessibility reveals the opposite conditions. Refugee camps were likely to be located in poorly connected areas (Table B.14 of Appendix B). That is also the case when restricting the analysis to the two bordering districts (see panel B of Table B.14 of Appendix B). No significant difference is found when controlling for the distance to the closest border. Results are also robust to the exclusion of the Benaco camp (or any other camp, excluded separately) from the construction of the refugee index.
} 
accessibility.

It is also possible to estimate the effect of roads on real consumption per capita by instrumenting roads with the refugee index. The main caveat here is that the exclusion restriction may not hold because refugees can affect real consumption through a variety of other channels. Keeping this important caveat in mind, we observe that the refugee-induced change in roads strongly raises real consumption per adult equivalent in a two-stage least squares estimation (panel B of Table B.15 in Appendix B). The first-stage regressions are given in panel $\mathrm{C}$. The magnitude of the response of real consumption to the refugeeinduced changes in road accessibility is almost identical to that in our main results. This is consistent with our conclusion that road accessibility seems to be the main driver of the welfare improvements found by 2010 in refugee-hosting areas. ${ }^{14}$

The welfare-improving impact of road accessibility in high-refugee areas is further corroborated by the decreasing effect on goods prices. Improved road infrastructure is indeed expected to decrease the price of traded goods, in particular in remote rural areas like Kagera (Casaburi et al., 2013). In Table 8, we assess the impact of the refugee presence on three price indexes, the Laspeyres, the Paasche, and the Fisher ideal price indexes, respectively, in panels A, B, and C. Such price indexes are based on 20 comparable goods, allowing us to distinguish between food and non-food consumption goods. The differences between the composition of these indexes and that of the food and non-food indexes are described in Appendix A. Columns 1 and 2 of Table 8 indicate that between 1991 and 2010, the presence of refugees had a decreasing and significant impact on consumption prices. The quasi-elasticity stands between 0.65 and 0.82 , depending on the index used. In columns 3 to 6 of all panels, the decreasing impact is driven by the prices of food items within the consumption basket. Such a price effect is supportive of the idea that a shift of equilibrium can be mainly explained by subsequent investment in road infrastructure in high-refugee areas.

\footnotetext{
${ }^{14}$ Then our main regression of real consumption per capita on the refugee index could be considered as a reduced-form estimate of a standard two-stage estimation.
} 
Table 8: Assessing the impact on prices

\begin{tabular}{|c|c|c|c|c|c|c|}
\hline & (1) & (2) & (3) & (4) & (5) & (6) \\
\hline Panel A & \multirow{2}{*}{\multicolumn{6}{|c|}{ Laspeyres price index }} \\
\hline Dep. var. & & & & & & \\
\hline Food vs. non-food & 20 items & 20 items & Food & Food & Non-food & Non-food \\
\hline$R I_{v, t}$ & $\begin{array}{c}-1.042^{* * *} \\
(0.132)\end{array}$ & $\begin{array}{c}-0.812^{* * *} \\
(0.174)\end{array}$ & $\begin{array}{c}-1.052^{* * *} \\
(0.127)\end{array}$ & $\begin{array}{c}-0.795^{* * *} \\
(0.159)\end{array}$ & $\begin{array}{c}0.011 \\
(0.029)\end{array}$ & $\begin{array}{c}-0.018 \\
(0.039)\end{array}$ \\
\hline$Q_{v, t}$ & No & Yes & No & Yes & No & Yes \\
\hline$\alpha_{t}$ & Yes & Yes & Yes & Yes & Yes & Yes \\
\hline$\alpha_{v}$ & Yes & Yes & Yes & Yes & Yes & Yes \\
\hline Observations & 102 & 102 & 102 & 102 & 102 & 102 \\
\hline R-squared & 0.992 & 0.995 & 0.989 & 0.994 & 0.979 & 0.988 \\
\hline Panel B & \multirow{2}{*}{\multicolumn{6}{|c|}{ Paasche price index }} \\
\hline Dep. var. & & & & & & \\
\hline Food vs. non-food & 20 items & 20 items & Food & Food & Non-food & Non-food \\
\hline$R I_{v, t}$ & $\begin{array}{c}-0.858^{* * *} \\
(0.124)\end{array}$ & $\begin{array}{c}-0.649^{* * *} \\
(0.173)\end{array}$ & $\begin{array}{c}-0.890^{* * *} \\
(0.119)\end{array}$ & $\begin{array}{c}-0.648^{* * *} \\
(0.156)\end{array}$ & $\begin{array}{c}0.032 \\
(0.036)\end{array}$ & $\begin{array}{l}-0.000 \\
(0.049)\end{array}$ \\
\hline Observations & 102 & 102 & 102 & 102 & 102 & 102 \\
\hline R-squared & 0.993 & 0.996 & 0.990 & 0.994 & 0.979 & 0.988 \\
\hline Panel C & \multirow{2}{*}{\multicolumn{6}{|c|}{ Fisher ideal price index }} \\
\hline Dep. var. & & & & & & \\
\hline Food vs. non-food & 20 items & 20 items & Food & Food & Non-food & Non-food \\
\hline$R I_{v, t}$ & $\begin{array}{c}-0.950^{* * *} \\
(0.128)\end{array}$ & $\begin{array}{c}-0.729^{* * *} \\
(0.173)\end{array}$ & $\begin{array}{c}-0.971^{* * *} \\
(0.123)\end{array}$ & $\begin{array}{c}-0.723^{* * *} \\
(0.157)\end{array}$ & $\begin{array}{c}0.022 \\
(0.032)\end{array}$ & $\begin{array}{c}-0.008 \\
(0.044)\end{array}$ \\
\hline$Q_{v, t}$ & No & Yes & No & Yes & No & Yes \\
\hline$\alpha_{t}$ & Yes & Yes & Yes & Yes & Yes & Yes \\
\hline$\alpha_{v}$ & Yes & Yes & Yes & Yes & Yes & Yes \\
\hline Observations & 102 & 102 & 102 & 102 & 102 & 102 \\
\hline R-squared & 0.993 & 0.995 & 0.990 & 0.992 & 0.979 & 0.988 \\
\hline
\end{tabular}

\subsection{Other Possible Channels}

The drastic decrease in transport costs caused by increased road provision is not the only possible explanation for the persistent positive impact of refugees. Both our fieldwork and the above theoretical framework point to two sets of alternative explanations resulting in either the switch to a new equilibrium in a multiple-equilibria setting or a shift in the existing equilibrium.

First, there is a long tradition in development economics of relating the multiplicity of equilibria to the existence of a poverty trap (Azariadis and Drazen, 1990; Murphy et al., 1989). For instance, Miguel and Roland (2011) formalized such a possibility in the case of Vietnam. There is no doubt that the imperfect nature of credit markets in rural Kagera is likely to generate poverty traps (De Weerdt, 2006). Conjecturing that the presence of refugees and the associated welfare improvement allows for an escape from such a poverty trap is another matter. In columns 1 to 3 of Table 9, we investigate the impact of the temporary 
inflows of refugees on poverty, defined as having a real consumption per capita lower than 253,530 Tzs. The description of the poverty line is given in Appendix A. A decrease in poverty is observed only by 2010 using a non-linear estimation in column 3. By 2010, poverty is reduced by about 17 percent. Nonetheless, such estimates are informative only as a means of shedding light on a change at the mean for the entire consumption distribution, while the non-linear estimation (with household fixed effects) draws inference based on the subsample of households, that change their poverty status. The breakup of the poverty trap should be consistent with a stronger impact at the lower part of the consumption distribution.

Implementing quantile regressions in columns 6 to 10, we confirm the positive impact along the consumption distribution but observe that the improvements in real consumption have not been concentrated in the lowest part of the consumption distribution, either by 2004 (panel A) or by 2010 (panel B). On the contrary, no statistical difference can be found across the lower and upper quantiles.

The existence of multiple equilibria is also consistent with the importance of agglomeration economies that could potentially be generated by the concentration of population. The inflow of refugees was indeed followed by an inflow of economic migrants attracted by the opportunities associated with the refugee camps. This second form of migration, which follows humanitarian aid, is documented by Buscher and Vlassenroot (2009) in other contexts. Importantly, many of these economic migrants stayed after the refugees left. As a result of increased population, agglomeration economies working through denser and more efficient labor markets (labor pooling), stronger backward and forward linkages, and increased spillovers allowing innovations to spread (Fujita and Thisse, 2002; Combes et al., 2008; Duranton and Puga, 2004) could explain part of the persistent impact of refugees. Anecdotal evidence in other countries suggests that refugee inflows may strengthen the urbanization process in the regions of destination (de Montclos and Kagwanja, 2000; Buscher and Vlassenroot, 2009; Alix-Garcia et al., 2013). Agglomeration economies may be measured by the total population reported by each village leader. These data are available only for 1991 and 2004. We also used population density, which is proxied by the average distance between each household and the center of its community. Panel A of Table 10 indicates, at least in the most complete regression, that the presence of refugees does not affect the proxies for agglomeration economies.

Next, the role of improved road accessibility in shifting the equilibrium may be confounded by other changes in local fundamentals. Based on our fieldwork observations, two possibilities appear as credible 
hypotheses. On the one hand, other public goods may have also played a role. Interviews with local authorities suggest that tax revenues strongly increased due to a surge in activity around refugee camps when they were open. These revenues may have been invested in growth-enhancing sectors such as education or health services. The provision of local public goods could also improve through a more subtle channel. Local authorities reported better management skills and institutional efficiency after dealing with international organizations. In turn, these enhancements could have helped local authorities to improve their subsequent collaborations with non-governmental organizations.

We can proxy for the provision of local public goods using data measuring the distance to the closest health facility (health dispensary, hospital, health center) and to education provider (secondary school -there was already a primary school in each village in 1991), as well as the sum of social services or nongovernmental organizations in the community. These data are available only for 1991 and 2004. Panels $\mathrm{B}$ and $\mathrm{C}$ of Table 10 reject that explanation. The presence of refugees has no effect on the accessibility of health and social services. Only the coefficients of the refugee index for the distance to the closest hospital and the number of non-governmental organizations are significantly different from zero at any reasonable level of confidence (column 4 of panel B and column 6 of panel C). These coefficients feature an unexpected sign in both cases and hence could not constitute credible explanations for the persistent change in welfare in high-refugee areas. ${ }^{15}$

Interviews conducted with Red Cross officers during our fieldwork point to a last possible channel of transmission. The persistence associated with refugee camp effects could be explained by the fact that many refugees repatriated just beyond the border and continued to trade with the local population. Such hypothesized trade channel would echo the facilitation of economic exchanges between displaced people (after their return) and the hosting communities in other contexts (Burchardi and Hassan, 2013). We compute total exports and imports between Tanzania and the three neighboring countries over the five years prior to 1991,2004 , and 2010, respectively. We then interact these bilateral trade flows with the distance of the surveyed villages to the border of these countries. Despite the above anecdotal evidence,

\footnotetext{
${ }^{15}$ Although not significant in the most complete specification (column 2 of panel $\mathrm{C}$ ), the negative association between the presence of refugees and the distance to the closest secondary school is suggestive of strong human capital accumulation in high-refugee areas. Nonetheless, applying conventional and quantile regressions similar to the ones used in Tables 2 and 9 replacing the dependent variable with the average education of the household, does not provide strong evidence for that channel. On the contrary, while no impact is found by 2004, the presence of refugees is associated with a decrease in education in high refugee areas by 2010. No statistical differences are found between lower and upper quantiles. Such difference is also incompatible with possible skill transferability between migrants and local hosts observed in other settings (Bazzi et al., 2014).
} 
Table 10 shows no strong impact of the refugee inflows on trade flows with neighboring countries.

We acknowledge that our exploration of alternative explanations may be limited by data availability and measurement errors. However, we do not find evidence that changes in the provision of local public goods, or in the role of agglomeration economies, or the enhanced trade with neighboring countries constitutes an alternative explanation for the persistent increase in real consumption in high-refugee areas compared with other areas. 
Table 9: Impact on poverty and consumption distribution

\begin{tabular}{|c|c|c|c|c|c|c|c|c|c|c|}
\hline \multirow{2}{*}{ Model } & \multirow{2}{*}{\multicolumn{2}{|c|}{$\begin{array}{c}\text { Linear } \\
\text { probability model }\end{array}$}} & \multirow{2}{*}{ Logit } & \multirow{2}{*}{\multicolumn{2}{|c|}{$\begin{array}{c}\text { Main results } \\
\text { mean }\end{array}$}} & \multicolumn{2}{|c|}{ Quantile regressions } & \multirow[b]{2}{*}{ q50 } & \multirow[b]{2}{*}{$\mathrm{q} 75$} & \multirow[b]{2}{*}{ q90 } \\
\hline & & & & & & q10 & $\mathrm{q} 25$ & & & \\
\hline & $(1)$ & $(2)$ & (3) & (4) & (5) & (6) & (7) & (8) & (9) & $(10)$ \\
\hline Dep. var. & \multicolumn{3}{|c|}{$\begin{array}{l}\text { Dummy for being poor } \\
\text { by } 2004\end{array}$} & \multicolumn{6}{|c|}{ Real consumption per adult equivalent, 1991 and 2004} & \\
\hline$R I_{v, t}$ & $\begin{array}{c}-0.014 \\
(0.020)\end{array}$ & $\begin{array}{l}-0.016 \\
(0.019)\end{array}$ & $\begin{array}{l}-0.170^{*} \\
(0.098)\end{array}$ & $\begin{array}{l}0.032^{*} \\
(0.018)\end{array}$ & $\begin{array}{c}0.049^{* * *} \\
(0.018)\end{array}$ & $\begin{array}{l}0.044^{*} \\
(0.026)\end{array}$ & $\begin{array}{c}0.038^{* *} \\
(0.016)\end{array}$ & $\begin{array}{c}0.046^{* * *} \\
(0.014)\end{array}$ & $\begin{array}{c}0.037^{* *} \\
(0.016)\end{array}$ & $\begin{array}{l}0.033^{*} \\
(0.019)\end{array}$ \\
\hline Observations & 5,230 & 5,230 & 1,838 & 5,23 & 5,230 & 5,230 & 5,230 & 5,230 & 5,230 & 5,230 \\
\hline$Z_{h, t}$ & Yes & Yes & Yes & Yes & Yes & Yes & Yes & Yes & Yes & Yes \\
\hline$Q_{v, t}$ & Yes & Yes & Yes & Yes & Yes & Yes & Yes & Yes & Yes & Yes \\
\hline$\alpha_{t}$ & Yes & Yes & Yes & Yes & Yes & Yes & Yes & Yes & Yes & Yes \\
\hline$\alpha_{h}$ & Yes & Yes & Yes & Yes & Yes & Yes & Yes & Yes & Yes & Yes \\
\hline$\alpha_{v}$ & No & yes & No & No & Yes & Yes & Yes & Yes & Yes & Yes \\
\hline $\begin{array}{l}\text { t-statistic: } \\
\text { Diff. from q10 }\end{array}$ & & & & & & & $\begin{array}{l}-0.004 \\
(0.021)\end{array}$ & $\begin{array}{c}0.004 \\
(0.019)\end{array}$ & $\begin{array}{l}-0.005 \\
(0.024)\end{array}$ & $\begin{array}{c}-0.009 \\
(0.030)\end{array}$ \\
\hline $\begin{array}{l}\text { t-statistic: } \\
\text { Diff. from q25 }\end{array}$ & & & & & & & & $\begin{array}{c}0.008 \\
(0.014) \\
\end{array}$ & $\begin{array}{l}-0.001 \\
(0.021) \\
\end{array}$ & $\begin{array}{l}-0.005 \\
(0.024) \\
\end{array}$ \\
\hline $\begin{array}{l}\text { Panel B } \\
\text { Dep. var. }\end{array}$ & $\begin{array}{l}\text { Dummy } \\
\text { by } 2010\end{array}$ & or being & & Real cor & amption pe & adult equiv & lent, 1991 & dd 2010 & & \\
\hline$R I_{v, t}$ & $\begin{array}{l}-0.069 \\
(0.053) \\
\end{array}$ & $\begin{array}{l}-0.050 \\
(0.066) \\
\end{array}$ & $\begin{array}{c}-0.326^{* *} \\
(0.148)\end{array}$ & $\begin{array}{r}0.078 * * \\
(0.033) \\
\end{array}$ & $\begin{array}{c}0.123 * * * \\
(0.035)\end{array}$ & $\begin{array}{c}0.115^{* * * *} \\
(0.033)\end{array}$ & $\begin{array}{c}0.137 * * * \\
(0.026) \\
\end{array}$ & $\begin{array}{c}0.086^{* * * *} \\
(0.018)\end{array}$ & $\begin{array}{c}0.093^{* * *} \\
(0.019) \\
\end{array}$ & $\begin{array}{r}0.110^{* * *} \\
(0.027) \\
\end{array}$ \\
\hline Observations & 6,236 & 5,788 & 1,874 & 5,788 & 5,788 & 5,788 & 5,788 & 5,788 & 5,788 & 5,788 \\
\hline$Z_{h, t}$ & Yes & Yes & Yes & Yes & Yes & Yes & Yes & Yes & Yes & Yes \\
\hline$Q_{v, t}$ & Yes & Yes & Yes & Yes & Yes & Yes & Yes & Yes & Yes & Yes \\
\hline$\alpha_{t}$ & Yes & Yes & Yes & Yes & Yes & Yes & Yes & Yes & Yes & Yes \\
\hline$\alpha_{h}$ & Yes & Yes & Yes & Yes & Yes & Yes & Yes & Yes & Yes & Yes \\
\hline$\alpha_{v}$ & No & yes & No & No & Yes & Yes & Yes & Yes & Yes & Yes \\
\hline $\begin{array}{l}\text { t-statistic: } \\
\text { Diff. from q10 }\end{array}$ & & & & & & & $\begin{array}{c}0.022 \\
(0.024)\end{array}$ & $\begin{array}{l}-0.029 \\
(0.039)\end{array}$ & $\begin{array}{l}-0.023 \\
(0.031)\end{array}$ & $\begin{array}{l}-0.006 \\
(0.043)\end{array}$ \\
\hline $\begin{array}{l}\text { t-statistic: } \\
\text { Diff. from q25 }\end{array}$ & & & & & & & & $\begin{array}{c}-0.051^{* *} \\
(0.020)\end{array}$ & $\begin{array}{c}-0.045^{* *} \\
(0.020)\end{array}$ & $\begin{array}{l}-0.028 \\
(0.030)\end{array}$ \\
\hline
\end{tabular}

Notes: Robust standard errors clustered at the initial village level in parentheses. ${ }^{*},{ }^{* *},{ }^{* * *}:$ significant at $10 \%, 5 \%$, and $1 \%$, respectively. 
Table 10: Assessing the role of other channels

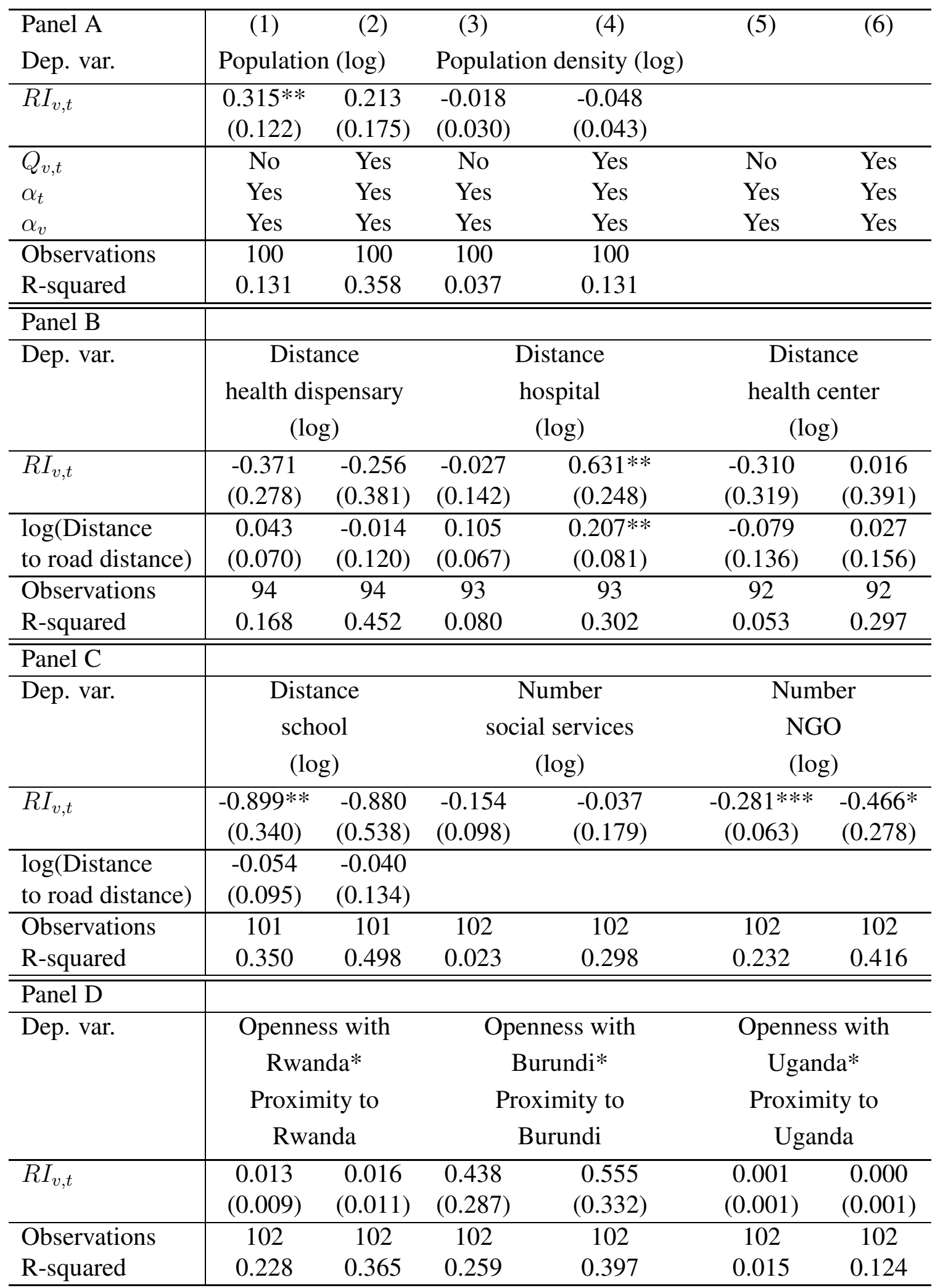

Notes: Robust standard errors in parentheses. ${ }^{*},{ }^{* *},{ }^{* *}$ : significant at $10 \%, 5 \%$, and $1 \%$, respectively. The same regressions are estimated in all panels. $Q_{v, t}$ includes not only include the monthly rainfall anomalies over the growing seasons of the last two years but also the individual and household characteristics aggregated at the initial village level. The household size is excluded in panel A for obvious endogeneity reasons. 


\section{Conclusions}

Our results indicate that the refugee presence significantly increased real consumption per adult equivalent between 1991 and 2004 and between 1991 and 2010, although most refugees left between 1996 and 2000. We then investigate the possible channels of transmission of such persistence. The most important channel of transmission is a sizable decrease in transport costs following increased road building. We interpret these changes as a shift in equilibrium induced by the shock that represents the massive refugee inflows in the region of Kagera in the 1990s. We find no evidence supporting the notion that multiple equilibria may have been at play.

The findings undercut the view, which is commonly held today, that forced migrants systematically constitute a burden for hosting communities. On the contrary, our results suggest that a new paradigm is needed when dealing with a protracted refugee situation. In the short run, the priorities should certainly be to improve the ability of the local population to cope with changes in the price of final goods and factors. Then, progressively, humanitarian assistance should give way to long-term developmental efforts, capitalizing on the road investments made by international organizations. In a context similar to our case study in Tanzania, we can conjecture that local integration of the refugees into the local economy could have certainly acted as a multiplier of the welfare-improving effects of better road conditions. Our results also indicate that fostering regional integration with neighboring countries may be an interesting secondbest option to consider when repatriation (or resettlement) is favored as a solution to a protracted refugee situation.

Finally, it is important to remain cautious about the generalizable nature of our results to other contexts. The positive path dependence emerging from the refugee inflows is not independent from the initial conditions prevailing at the time of arrival of the refugees. First, the fact that land availability is not a major constraint in the region of Kagera certainly eased the integration of refugees into the local economy. However, the region of Kagera was not necessarily an exception. Anecdotal evidence from Kenya and Uganda (Mabiso et al., 2014) also suggests positive outcomes (with potential redistribution effects) resulting from large refugee inflows. Second, there were no major historical grievances against refugees in northwestern Tanzania. In contrast, the security concerns were much higher when refugees from Rwanda (in particular the genocidaires) moved to eastern Democratic Republic of Congo where ethnic tensions 
constitute a strong historical legacy. Still, there is no reason to believe that the developmental benefits from road infrastructure could not be reaped in other rural economies. A question for further research is whether these benefits would have been so large without the dynamics initially induced by the establishment of refugee camps and the presence of a road construction company in the region. One limitation of our present analysis is that we are not able to qualify the optimal nature of the shift in equilibrium. Road investment has certainly been beneficial, but we cannot exclude the idea that a social planner could have possibly increased social welfare by building roads in other areas. The question of optimality of a new spatial equilibrium is a key question for further research (Jedwab et al., 2013) and would call for more research on the costs of new infrastructure and its maintenance. 


\section{References}

Adams, R. and Page, J. (2005). Do International Migration and Remittances Reduce Poverty in Developing Countries? World Development, 33(10):1645-1669.

Alix-Garcia, J., Bartlett, A., and Saah, D. (2013). The Landscape of Conflict: IDPs, Aid, and Land Use Change in Darfur. Journal of Economic Geography, 13(4):589-617.

Alix-Garcia, J. and Saah, D. (2010). The Effect of Refugee Inflows on Host Communities: Evidence from Tanzania. World Bank Economic Review, 24(1):148-170.

Angrist, J. and Kugler, A. (2003). Protective or Counter-productive? Labour Market Institutions and the Effect of Immigration on EU Natives. Economic Journal, 113:302-331.

Azam, J.-P. and Hoeffler, A. (2002). Violence against Civilians in Civil Wars: Looting or Terror. Journal of Peace Research, 39(4):461-485.

Azariadis, C. and Drazen, A. (1990). Threshold Externalities in Economic Development. Quarterly Journal of Economics, 105(2):501-526.

Baez, J. E. (2011). Civil Wars Beyond Their Borders: The Human Capital and Health Consequences of Hosting Refugees. Journal of Development Economics, 96:391-408.

Banerjee, A., Duflo, E., and Qian, N. (2012). On the Road: Access to Transportation Infrastructure and Economic Growth in China. Working paper 17897. Cambridge, MA, US: National Bureau of Economic Research.

Baum-Snow, N. (2007). Did Highways Cause Suburbanization? Quarterly Journal of Economics, 122(2):775-805.

Baum-Snow, N., Brandt, L., Henderson, V., Turner, M., and Zhang, Q. (2013). Roads, Railroads and Decentralization of Chinese Cities. Unpublished.

Bazzi, S., Gaduh, A., Rothernberg, A., and Wong, M. (2014). Skill Transferability, Migration, and Development: Evidence from Population Ressetlement in Indonesia. Unpublished Paper Presented at the Migration and Development Conference (Oxford, July 2014). 
Beegle, K., De Weerdt, J., and Dercon, S. (2006). Kagera Health and Development Survey 2004 Basic Information Document. Unpublished, The World Bank, Washington, DC.

Beegle, K., De Weerdt, J., and Dercon, S. (2011). Migration and Economic Mobility in Tanzania. Evidence from a Tracking Survey. Review of Economics and Statistics, 93(3):1010-1033.

Beegle, K., De Weerdt, J., Friedman, J., and Gibson, J. (2012). Methods of Household Consumption Measurement through Surveys: Experimental Results from Tanzania. Journal of Development Economics, 98:19-33.

Bengtsson, N. (2010). How Responsive Is Body Weight to Transitory Changes? Evidence from Rural Tanzania. Journal of Development Economics, 92(1):53-61.

Berry, L. (2008). The Impact of Environmental Degradation on Refugee-Host Relations: A Case Study from Tanzania. Research Paper United nationas High Commissioner for Refugees Evaluation and Policy Analysis unit, 151.

Bertrand, M., Duflo, E., and Mullainathan, S. (2004). How Much Should We Trust Differences-inDifferences Estimates. Quarterly Journal of Economics, 119(1):249-275.

Bleakley, H. and Lin, J. (2012). Portage and Path Dependence. Quarterly Journal of Economics, 127:587644.

Borjas, G. (1999). The Economic Analyses of Immigration. In Ashenfelter, O. and Card, D., editors, Handbook of Labour Economics, volume 3A, pages 1967-1760. Amsterdam: North Holland.

Bosker, M., Brakman, S., Garretsen, H., and Schramm, M. (2007). Looking for Multiple Equilibria When Geography Matters: German City Growth and the WWII Shock. Journal of Urban Economics, 61(1):152-169.

Brakman, S., Garretsen, H., and Schramm, M. (2004). The spatial Distribution of Wages and Employment: Estimating the Helpman-Hanson Model for Germany. Journal of Regional Science, 44(3):437466. 
Burchardi, K. and Hassan, T. (2013). The Economic Impact of Social Ties: Evidence from German Reunification. Quarterly Journal of Economics, pages 1219-1271.

Buscher, K. and Vlassenroot, K. (2009). Humanitarian Presence and Urban Development: New Opportunities and Contrasts in Goma, DRC. Disasters, 34(2):256-273.

Card, D. (1990). The Impact of the Mariel Boatlift on the Miami Labor Markets. Industrial and Labor Relations Review, 43(2):245-257.

Card, D. (2005). Is the New Immigration Really So Bad? Economic Journal, 115(507):300-323.

Casaburi, L., Glennerster, R., and Suri, T. (2013). Rural Roads and Intermediated Trade: Regression Discontinuity: Evidence from Sierra Leone. Unpublished.

Collier, P., Radwan, P., Wangwe, S., and Wangwe, A. (1986). Labour and Poverty in Rural Tanzania. Oxford UK: Oxford University Press; Geneva: International Labor Organization, Oxford.

Combes, P.-P., Mayer, T., and Thisse, J.-F. (2008). Economic Geography: The Integration of Regions and Nations. Princeton, NJ, US: Princeton University Press.

Davis, D. R. and Weinstein, D. E. (2002). Bones, Bombs and Breakpoints: The Geography of Economic Activity. American Economic Review, 92(5):1269-1289.

de Montclos, M.-A. P. and Kagwanja, P. M. (2000). Refugee Camps or Cities? The Socio-economic Dynamics of the Dadaab and Kakuma Camps in Northern Kenya. Journal of Refugee Studies, 13(2):205222.

De Weerdt, J. (2006). Moving Out of Poverty in Tanzania's Kagera Region. Prepared for the World bank's Moving Out of poverty Study. Bukoba, Tanzania: Economic Development Initiatives.

De Weerdt, J., Beegle, K., Lilleor, H., Dercon, S., Hirvonen, K., Kirchberger, M., and Krutilov, S. (2010). Kagera Health and Development Survey 2010: Basic Information Document. Study paper 6. Copenhagen: Rockwool Foundation Working.

De Weerdt, J. and Hirvonen, K. (2012). Risk Sharing and Migration in Tanzania. Unpublished. 
Djemai, E. (2009). How do Roads Spread AIDS in Africa? A Critique of the Received Policy Wisdom. Working Paper 09-120. Toulouse, france: Toulouse School of Economics.

Docquier, F., Ozden, C., and Peri, G. (forthcoming). The labor market impact of immigration in OECD countries. Economic Journal.

Donaldson, D. (forthcoming). Railroads of the Raj: Estimating the Impact of Transportation Infrastructure. American Economic Review.

Driscoll, J. and Kraay, A. (1998). Consistent Covariance Matrix Estimation with Spatially Dependent Panel Data. Review of Economics and Statistics, 80:549-560.

Duranton, G., Morrow, P. M., and Turner, M. A. (2013). Roads and Trade: Evidence from the US. Review of Economic Studies, (81):681-724.

Duranton, G. and Puga, D. (2004). Micro-foundations of Urban Agglomeration Economies. In Henderson, V. and Thisse, J.-F., editors, Handbook of Regional and Urban Economics, volume IV, chapter 48, pages 2063-2117. Amsterdam: North Holland.

Duranton, G. and Turner, M. A. (2012). Urban Growth and Transportation. Review of Economic Studies, 79(4):1407-1440.

Faber, B. (2014). Trade Integration, Market Size, and Industrialization: Evidence from China's National Trunk Highway System. Review of Economic Studies, 81:1046-1070.

Fujita, M. and Thisse, J. (2002). Economics of Agglomeration, Cities, Industrial Location and Regional Growth. Cambridge, MA, US: Cambridge University Press.

Gachassin, M. C. (2013). Should I Stay or Should I Go? The Role of Roads in Migration Decisions. Journal of African Economies, 22(5):796-826.

Ghani, E., Goswami, A. G., and Kerr, W. (2012). Highway to Success: The Impact of the Golden Quadrilateral Project for the Location and Performance of Indian Manufacturing. Working Paper 18524. Cambridge, MA, US: National Bureau of Economic Research. 
Gibson, J. and Rozelle, S. (2005). Prices and Unit Values in Poverty Measurement and Tax Reform Analysis. World Bank Economic Review, 27(2):69-97.

Grogger, J. and Hanson, G. (2011). Income Maximization and the Selection and Sorting of International Migrants. Journal of Development Economics, 95(1):42-57.

Grosh, M. and Glewwe, P. (1995). A Guide to Living Standards Measurement Study Surveys and Their Data Sets. Living Standard Measurement Study (LSMS) working paper 120. Washington, DC: World Bank.

Hanson, G. H. (2009). The Economic Consequences of the International Migration of Labor. Annual Review of Economics, 1:179-208.

Hatton, T. J. and Tani, M. (2005). Immigration and Inter-regional Mobility in the UK, 1982-2000. Economic Journal, (115):342-358.

Heston, A., Summers, R., and Aten, B. (2006). Penn World Table Version 6.2. Center for International Comparisons of Production, Income and Prices at the University of Pennsylvania. Accessed on June $24,2013$.

Hirvonen, K. (2013). Temperature Shocks, Household Consumption and Internal Migration: Evidence from Rural Tanzania. Unpublished.

Jacoby, H. (2000). Access to Markets and the Benefits of Rural Roads. Economic Journal, 465:713-737.

Jacoby, H. and Minten, B. (2009). On Measuring the Benefits of Lower Transport Costs. Journal of Development Economics, 89:28-38.

Jedwab, R., Kerby, E., and Moradi, A. (2013). History, Path Dependence and Development: Evidence from Colonial Railroads, Settlers and Cities in Kenya. Unpublished.

Jedwab, R. and Moradi, A. (2013). Transportation Technology and Economic Change: Evidence from Colonial Railroads and City Growth in Africa. Unpublished.

Khandker, S., Bakht, Z., and Boolwal, G. (2009). The Poverty Impact of Rural Roads: Evidence from Bangladesh. Economic Development and Cultural Change, 57(4):685-722. 
Mabiso, A., Maystadt, J.-F., Hirvonen, K., and Vandercasteelen, J. (2014). Refugees and Food Security in Host Communities: A Review of Impacts and Policy Options to Enhance Resilience. 2020 Conference paper 2. Washington, DC: International food Policy Research Institute.

Martin, P., Mayer, T., and Thoenig, M. (2008). Make Trade Not War. Review of Economic Studies, 75(3):865-900.

Maystadt, J.-F. and Verwimp, P. (2014). Winners and Losers Among a Refugee-Hosting Population. Economic Development and Cultural Change, 62(4):769-809.

Michael, G. (2008). The Effect of Trade on the Demand for Skill: Evidence from the Interstate Highway System. Review of Economics and Statistics, 90(4):683-701.

Miguel, E. and Roland, G. (2011). The Long-Run Impact of Bombing Vietnam. Journal of Development Economics, 96(1):1-15.

Montalvo, J. G. and Reynal-Querol, M. (2007). Fighting against Malaria: Prevent Wars While Waiting for "Miraculous" Vaccine. Review of Economics and Statistics, 89(1):165-177.

Moulton, B. (1986). Random Group Effects and the Precision of Regression Estimates. Journal of Econometrics, 32:385-397.

Murphy, K. M., Shleifer, A., and Vishny, R. (1989). Income Distribution, Market Size and Industrialization. Quarterly Journal of Economics, 104:537-564.

Ottaviano, G. and Peri, G. (2012). Rethinking the Effects of Immigration on Wages. Journal of the European Economic Association, 10(1):152-197.

Psacharopoulos, G. (1994). Returns to Investment in Education: A Global Update. World Development, 22(9):1325-1343.

Redding, S., Sturm, D., and Wolf, N. (2011). History and Industrial Location: Evidence from German Airports. Review of Economics and Statistics, 93(3):814-831.

Rosenzweig, M. (2007). Education and Migration: A Global Perspective. Unpublished, Yale University, New haven, CT, US. 
Ruiz, I. and Vargas-Silva, C. (2013). The Economics of Forced Migration. The Journal of Development Studies, 49(6):772-784.

Rutinwa, B. (2002). The End of Asylum? The Changing Nature of Refugee Policies in Africa. Refugee Survey Quarterly, 21(1-2):12-41.

Salehyan, I. (2008). The Externalities of Civil Strife: Refugees as a Source of International Conflict. American Journal of Political Science, 52(4):787-801.

Sarvimaki, M. (2011). Agglomeration in the Periphery. Discussion Paper 0080. London: Spatial Economics research Centre, London School of Economics.

Schultz, P. (1999). Health and Schooling Investments in Africa. Journal of Economic Perspectives, 13(3):67-88.

Storeygard, A. (2011). Farther on Down the Road: Transport Costs, Trade and Urban Growth in subSaharan Africa. Policy Research Working Paper 6444. Washington, DC: World Bank.

Strauss, J. and Thomas, D. (1998). Health, Nutrition, and Economic Development. Journal of Economic Literature, 36(2):766-817.

Strauss, J. and Thomas, D. (2008). Health over the Life Course. In Schultz, P. and Strauss, J., editors, Handbook of Development Economics, volume 4, pages 3375-3484. Amsterdam: Elsevier.

Tanzania, NBS(National Bureau of Statistics) (2003). Kagera region socio-economic profile. Dar es Salaam: NBS and Kagera Regional Commissioner.

Tanzanian Affairs (1994). Benaco -2010 Tanzania’s Second City? Online.

Udry, C. (2003). Fieldwork, Economic theory and Research on Institutions in Developing Countries. Unpublished.

United Nations High Commissioner for Refugees (2012). 2011 Global Trends: A Year of Crises. Geneva.

Whitaker, B. E. (1999). Changing Opportunities: Refugees and Host Communities in Western Tanzania. Journal of Humanitarian Assistance, 4(1):1-23. 
Woodruff, C. and Zenteno, R. (2007). Migration Networks and Microenterprises in Mexico. Journal of Development Economics, 82(2):509-528.

Yang, D. (2008). International Migration, Remittances, and Household Investment: Evidence from Philippine Migrants’ Exchange Rate Shocks. Economic Journal, 118(528):591-630. 


\section{Appendix A Data}

Sample structure over time. Of the initial 915 households surveyed from 1991 to 1994, the field team managed to recontact 832 of them (see Beegle et al., 2006, for more details). Because many individuals had moved out from their original households (children in particular), the recontacted individuals from 1991 were part of 2,770 households interviewed for the 2004 KHDS. This number includes individuals who had moved out of their village of origin, the Kagera region, and even Tanzania since 1991. In 2010, a follow-up survey (wave 6) was administered to re-interview all respondents ever interviewed in the KHDS 1991-1994. That resulted in a sample of 3,314 households, originating from the 915 initial households. Despite almost 20 years' having elapsed since the first interviews, the field team achieved recontact with $92 \%$ of the original households.

Sample definition. Several complications result from the multiplication of surveyed households over time and the links among the households. ${ }^{16}$ The samples may be better defined in terms of a fictional household. In table A.1, we represent the way an original household with five members can multiply into four households in 2004 and six households in 2010. That example shows that the number of households originating from the same original household multiplies in 2004 because household members either create a new household (individuals 3 and 5 in 1991 create households with ID numbers 1000 and 1002) or join another non-surveyed household (member 4 in 1991 joins household ID 1001).

New households are usually named after a split-off household. In turn, children of these households can also create or join new households in 2010. Special cases exist if, for example, a household member joins a previously surveyed household, causing, the split-off households to be linked to two original households. In that case, we link the newly joined households to the original household of the majority of the household members, or we keep the original household of the household head.

The baseline analysis is based on 3,314 households, including households who had migrated outside of Kagera by 2004 and 2010. Due to missing consumption data, 207 households are excluded. The sample

\footnotetext{
${ }^{16}$ In the 2004 KHDS, in the migration section, the identification of a split-off household was made possible thanks to the following question ( $\mathrm{s} 9 \mathrm{q} 1$ ): "Is the current household living in the same homestead (same plot or house) as households interviewed 10 years ago?". In 2010, no question similar to s9q1 is available. We use the information related to RelR2 (Relation to the Head KHDS 2004) because we are interested in identifying the households that split-off between 2004 and 2010 . Basically, we will define a split-off household in 2010 when a household head is different from its original household head in 2004 . For consistency reasons, we also compute the same variable compared with the original household from 1991 to 1994 . Nonetheless, when the analysis is performed on the period 1991-2004, the results are similar when using the more accurate question s9q1.
} 
Table A.1: Illustration of household structure and links with original households

\begin{tabular}{ccc|cc|cc}
\multicolumn{2}{c}{1991} & & \multicolumn{2}{c}{2004} & \multicolumn{2}{c}{2010} \\
HH member & HH 1991 & Status & HH 2004 & Status & HH 2010 & Status \\
\hline \hline 1 & 1 & Head & 1 & Head & 1 & Dead \\
2 & 1 & Wife & 1 & Wife & 1 & Head \\
\hline 3 & 1 & Child & 1000 & Head & 1000 & Head \\
& & & 1000 & Wife & 1000 & Wife \\
& & & 1000 & Child & 1000 & Child \\
\hline & & & 1000 & Child & 2900 & Head \\
& & & & & 2900 & Child \\
& & & & & 2900 & Child \\
\hline 4 & 1 & Child & 1001 & Wife & 1001 & \\
& & & 1001 & Head & 1001 & \\
\hline 5 & 1 & Child & 1001 & Child & 1001 & \\
\hline & & & 1002 & Head & 1002 & \\
& & & 1002 & Child & 1002 & \\
\hline & & & & & 3000 & Child \\
& & & & & 3000 & Child \\
& & & & & 3000 & Child
\end{tabular}

Source: Authors' own construction.

Note $: \mathrm{HH}=$ Household. The numbers constitute fictive illustrations of possible household identification codes.

is reduced to 2,572 households when we exclude the migrants. That sample still includes those moving to a nearby village. While excluding those moving within Kagera, the sample is reduced to about 1,700 households. Table A. 2 provides further information about attrition and migration. Note that all our results are shown to be robust to the different samples, including those who have changed location by 2004 and 2010.

Consumption data are fully comparable for the years 1991, 2004, and 2010, because they use the same recall periods. The recall period for the consumption module in 1992, 1993, and 1994 was reduced from 12 to 6 months. That is an important issue given the sensitivity of consumption data to seasonality and the bias a different period may introduce (Beegle et al., 2012). The aggregated consumption data defined in 1991, 2004, and 2010 and provided by Economic Development Initiatives (http : //www.edi - africa.com) have been used for comparability reasons (recall periods, common definition of components). The consumption basket comprises 20 items. There are 15 food items 
Table A.2: Attrition and migration rates

Descriptive statistics for 2004

\begin{tabular}{|c|c|c|c|}
\hline & $\begin{array}{c}\text { Attrition } \\
\text { since 1991 }\end{array}$ & $\begin{array}{c}\text { Migration } \\
\text { all (since 1991) }\end{array}$ & $\begin{array}{c}\text { Migration outside } \\
\text { of Kagera ( since 1991) }\end{array}$ \\
\hline Refugee-hosting areas & 0.05 & 0.19 & 0.06 \\
\hline Other areas & 0.1 & 0.32 & 0.11 \\
\hline All areas & 0.09 & 0.31 & 0.11 \\
\hline \multicolumn{4}{|c|}{ "Descriptive statistics for 2010} \\
\hline & $\begin{array}{c}\text { Attrition } \\
\text { since } 1991\end{array}$ & $\begin{array}{c}\text { Migration } \\
\text { all (since 1991) }\end{array}$ & $\begin{array}{c}\text { Migration outside } \\
\text { of Kagera ( } \text { since 1991) }\end{array}$ \\
\hline Refugee-hosting areas & 0.08 & 0.38 & 0.06 \\
\hline Other areas & 0.13 & 0.46 & 0.19 \\
\hline All areas & 0.12 & 0.46 & 0.18 \\
\hline
\end{tabular}

(beef, chicken, chicken eggs, cooking bananas, cooking oil, dried beans, Fresh milk, groundnuts, onions, raw cassava, rice, sorghum, sugar, sweet potato and tomatoes) and 5 non-food items (battery, charcoal, kerosene, linen, local Brew). We transform these consumption data in real terms (2010 Tanzanian shillings), using the Fisher ideal index described below).

The poverty status of each household is based on the consumption data described above as well as a poverty line similar to the one constructed by Beegle et al. (2011). In particular, these authors calibrated the poverty line on their sample of households who remained in Kagera to yield the same poverty rate as the 2000-2001 National Household Survey estimate for Kagera (29 percent). The same calibration can be performed on the non-migrant households of 2004 who were reinterviewed in 2010 to find a poverty line of 253,530 Tzs, expressed in 2010 values. We thank Kalle Hirvonen, who assented to share his code for that calibration exercise.

Price data have been aggregated by EDI (http : //www.edi-africa.com). We apply the same method to construct three prices indexes (Laspeyres, Paasche, and Fisher), distinguishing between food and non-food prices. The Laspeyres index compares the changes in prices assuming constant shares of expenditures, defined in 1991, between the 20 items composing the consumption basket. The Paasche index compares the change in prices assuming constant shares of expenditures, but defined in 2010, between the 20 items composing the consumption basket. The Fisher ideal index is a composite index of the two, potentially taking into account changes in the allocation within the consumption baskets. The Fisher 
ideal price index is indeed a combination of the square root of the sum of the deviation of price of each item compared with its baseline price, weighted by the budget share of each item in 1991 and 2010 (see http : //www.edi - africa.com). In 2010, price data were reported by individuals, although previous rounds collected prices at the village level (proxying the price index for the migrants by regional and national inflation figures). Individual reporting prices have been found to provide major quality improvements (Gibson and Rozelle, 2005). A logarithm transformation is also applied when the price indexes are used as dependent variable.

Rainfall data in total millimeters of rain per month from 1980 to 2010 are available from the Tanzanian Meteorological Agency based on more than 200 weather stations. Similar to Hirvonen (2013) and De Weerdt and Hirvonen (2012), an inverse distance weighting method is applied to link each household to the rainfall data. We thank Kalle Hirvonen, who assented to share his code for the inverse distance weighting method. Rainfall data are transformed into anomalies, that is, deviations from the long-term mean (1980-2010), divided by its long-run standard deviation. Anomalies during the growing periods should capture deviations from the normal conditions for agricultural production. The growing periods cover the months of March, April, May, October, November, and December).

Road accessibility are computed based on two road networks. First, data on road networks for the year 1991 are based on the DIVA-GIS (www.diva - gis.org) road network, excluding trails for comparability reasons with the 2005 data. The road network from 2005 comes from the Tanzanian National Roads Agency. For each, the Euclidian distance between each village and the closest road network is computed. We also compute the lengths of the roads, within buffers of different sizes (5, 10, 15, and 20 kilometers) around each village. Information on road rehabilitation is derived from Gachassin (2013).

Access to local public goods is based on the evaluation of the community leaders. The KHDS indeed provides community data based on a separate community survey addressed to the community leader. We define the following dependent variables: the distance needed to go to the closest health dispensary, the closest hospital, and the closest health center; the distance needed to go to the closest secondary school (all villages have a primary school, so that there is no variation in that dimension); the sum of social services or organizations operating in the community. ${ }^{17}$

Population in each village for each year is approximated by the village leader in the community

\footnotetext{
${ }^{17}$ The related question is "Do any of the following social services or organizations (Daycare Centre, Tanzanian Red Cross, Partage Assistance, Bakwata, World Vision assistance, Roman Catholic Assistance, Others) exist in this community?”
} 
survey of the KHDS database (unfortunately not in 2010). We also construct a proxy for population density. Economic Development Initiative, the company that collected the data in the region of Kagera, has made available the distance between each household and the center of its community. Assuming that the village has a monocentric structure, we can estimate the area of each village for example using the average distance between the household and the community center.

Trade-related flows are proxied as interaction terms between distance-to-the-border data and bilateral trade data, similar to Djemai (2009). We interact the Euclidian distance with time-varying bilateral trade data. Bilateral (or dyadic) trade data from the Correlates of War projects (Martin et al., 2008) are used to compute the total imports or exports from and to neighboring countries. These data are limited to 2006. We complete these data with bilateral trade data from ComTrade between 2007 and 2010. We compute total exports and imports for periods of five years prior to 1991, 2004, and 2010, respectively. We then use the real gross domestic product (GDP) data from the World Penn table (Heston et al., 2006) to compute a measure of trade openness with the three neighboring countries as the ratio of each country's total bilateral trade with Tanzania to its real GDP. We also compute the same ratio, using only total exports as a numerator. Using only exports provide similar results, though they are not reported. 


\title{
Separate Appendixes with Supplemental Material for:
}

\section{The Development Push of Refugees: Evidence from Tanzania}

\author{
Jean-François Maystadt* \\ Gilles Duranton ${ }^{\dagger}$
}

October 9, 2014

\begin{abstract}
This document contains a set of appendixes with supplemental material.
\end{abstract}

Keywords: Refugees; Tanzania; Multiple equilibrium; Roads.

JEL Classification: I32; O18; Q54

${ }^{*}$ Department of Economics, Lancaster University Management School, Lancaster, LA1 4YX, UK. Email: j.maystadt lancaster.ac.uk.

†Wharton School, University of Pennsylvania, Philadelphia, PA 19104; and CEPR. E-mail: duranton@wharton. upenn. edu 


\section{Appendix B Supplementary Tables}

Table B.3: The location of refugee camps in the Kagera region

\begin{tabular}{|c|c|c|c|c|c|c|}
\hline $\begin{array}{l}\text { Panel A } \\
\text { Dep. var. }\end{array}$ & \multicolumn{5}{|c|}{ Refugee index } & (6) \\
\hline Sample & \multicolumn{6}{|c|}{ Region of Kagera (6 districts) } \\
\hline $\log \left(\frac{C_{h, 1991}}{P_{v, 1991}}\right)$ & $\begin{array}{c}-0.185^{* *} \\
(0.085)\end{array}$ & $\begin{array}{c}-0.050^{* *} \\
(0.023)\end{array}$ & $\begin{array}{l}-0.157^{*} \\
(0.080)\end{array}$ & $\begin{array}{c}-0.058^{* *} \\
(0.026)\end{array}$ & $\begin{array}{c}-0.160^{* * *} \\
(0.059)\end{array}$ & $\begin{array}{c}-0.053^{* *} \\
(0.025)\end{array}$ \\
\hline $\begin{array}{l}\text { Distance } \\
\text { to Rwanda }\end{array}$ & & $\begin{array}{c}-4.190^{* * *} \\
(1.093)\end{array}$ & & $\begin{array}{c}-4.188^{* * *} \\
(1.066)\end{array}$ & & $\begin{array}{c}-5.253^{* * *} \\
(1.059)\end{array}$ \\
\hline $\begin{array}{l}\text { Distance } \\
\text { to Burundi }\end{array}$ & & $\begin{array}{c}-3.688^{* * *} \\
(0.772)\end{array}$ & & $\begin{array}{c}-3.785^{* * *} \\
(0.762)\end{array}$ & & $\begin{array}{c}-3.898^{* * *} \\
(0.713)\end{array}$ \\
\hline $\begin{array}{l}Z_{h, 1991} \\
Q_{v, 1991}\end{array}$ & $\begin{array}{l}\text { No } \\
\text { No }\end{array}$ & $\begin{array}{l}\text { No } \\
\text { No }\end{array}$ & $\begin{array}{l}\text { Yes } \\
\text { No }\end{array}$ & $\begin{array}{l}\text { Yes } \\
\text { No }\end{array}$ & $\begin{array}{l}\text { Yes } \\
\text { Yes }\end{array}$ & $\begin{array}{l}\text { Yes } \\
\text { Yes }\end{array}$ \\
\hline $\begin{array}{l}\text { Observations } \\
\text { R-squared }\end{array}$ & $\begin{array}{l}2,899 \\
0.032\end{array}$ & $\begin{array}{l}2,899 \\
0.853\end{array}$ & $\begin{array}{l}2,899 \\
0.128\end{array}$ & $\begin{array}{l}2,899 \\
0.856\end{array}$ & $\begin{array}{l}2,899 \\
0.342\end{array}$ & $\begin{array}{l}2,899 \\
0.870\end{array}$ \\
\hline $\begin{array}{l}\text { Panel B } \\
\text { Dep. var. }\end{array}$ & \multicolumn{6}{|c|}{ Refugee index } \\
\hline Sample & \multicolumn{6}{|c|}{ Districts of Ngara and Karagwe } \\
\hline $\log \left(\frac{C_{h, 1991}}{P_{v, 1991}}\right)$ & $\begin{array}{c}-0.516^{* * *} \\
(0.077)\end{array}$ & $\begin{array}{c}0.014 \\
(0.013)\end{array}$ & $\begin{array}{c}-0.379^{* * *} \\
(0.107)\end{array}$ & $\begin{array}{c}0.012 \\
(0.010)\end{array}$ & $\begin{array}{c}-0.388^{* * *} \\
(0.105)\end{array}$ & $\begin{array}{c}0.013 \\
(0.010)\end{array}$ \\
\hline $\begin{array}{l}\text { Distance } \\
\text { to Rwanda }\end{array}$ & & $\begin{array}{c}-28.919^{* * *} \\
(4.775)\end{array}$ & & $\begin{array}{c}-28.768^{* * *} \\
(4.717)\end{array}$ & & $\begin{array}{c}-28.972^{* * *} \\
(4.669)\end{array}$ \\
\hline $\begin{array}{l}\text { Distance } \\
\text { to Burundi }\end{array}$ & & $\begin{array}{c}-3.292^{* * *} \\
(0.701)\end{array}$ & & $\begin{array}{c}-3.309^{* * *} \\
(0.696)\end{array}$ & & $\begin{array}{c}-3.291^{* * *} \\
(0.687)\end{array}$ \\
\hline $\begin{array}{l}Z_{h, 1991} \\
Q_{v, 1991}\end{array}$ & $\begin{array}{l}\text { No } \\
\text { No }\end{array}$ & $\begin{array}{l}\text { No } \\
\text { No }\end{array}$ & $\begin{array}{l}\text { Yes } \\
\text { No }\end{array}$ & $\begin{array}{l}\text { Yes } \\
\text { No }\end{array}$ & $\begin{array}{l}\text { Yes } \\
\text { Yes }\end{array}$ & $\begin{array}{l}\text { Yes } \\
\text { Yes }\end{array}$ \\
\hline Observations & 677 & 677 & 677 & 677 & 677 & 677 \\
\hline R-squared & 0.188 & 0.989 & 0.287 & 0.989 & 0.314 & 0.989 \\
\hline
\end{tabular}

Notes: Robust standard errors clustered at the initial village level in parentheses. ${ }^{*},{ }^{* *},{ }^{* *}$ : significant at $10 \%, 5 \%$, and $1 \%$, respectively. Distances to borders are expressed in meters $\left(* 10^{6}\right)$. 
Table B.4: Detailed results for panel A of the main results (Table 2)

\begin{tabular}{|c|c|c|c|c|c|c|c|c|}
\hline \multirow[b]{2}{*}{ Dep. var. } & (1) & (2) & (3) & (4) & $(5)$ & (6) & (7) & $(8)$ \\
\hline & \multicolumn{8}{|c|}{ Real consumption per adult equivalent, 1991 and 2004} \\
\hline$R I_{v, t}$ & $\begin{array}{c}0.020 \\
(0.022)\end{array}$ & $\begin{array}{c}0.031 \\
(0.020)\end{array}$ & $\begin{array}{l}0.037^{*} \\
(0.020)\end{array}$ & $\begin{array}{l}0.049^{* *} \\
(0.019)\end{array}$ & $\begin{array}{c}0.020 \\
(0.019)\end{array}$ & $\begin{array}{c}0.030 \\
(0.021)\end{array}$ & $\begin{array}{l}0.032^{*} \\
(0.018)\end{array}$ & $\begin{array}{c}0.050^{* * *} \\
(0.018)\end{array}$ \\
\hline Age of & & & & & 0.001 & -0.003 & 0.001 & 0.000 \\
\hline head & & & & & $(0.006)$ & $(0.005)$ & $(0.006)$ & $(0.005)$ \\
\hline Age of & & & & & -0.000 & 0.000 & -0.000 & -0.000 \\
\hline head $^{2}$ & & & & & $(0.000)$ & $(0.000)$ & $(0.000)$ & $(0.000)$ \\
\hline Educ. of & & & & & -0.007 & -0.000 & -0.006 & $-0.008^{*}$ \\
\hline head & & & & & $(0.004)$ & $(0.004)$ & $(0.004)$ & $(0.004)$ \\
\hline Chr. ill. & & & & & $-0.049 *$ & -0.047 & $-0.054^{* *}$ & -0.041 \\
\hline of head & & & & & $(0.025)$ & $(0.029)$ & $(0.025)$ & $(0.026)$ \\
\hline $\begin{array}{l}\text { Fem. and non } \\
\text { married head }\end{array}$ & & & & & $\begin{array}{c}-0.168^{* * *} \\
(0.032)\end{array}$ & $\begin{array}{c}-0.199^{* * *} \\
(0.032)\end{array}$ & $\begin{array}{c}-0.166^{* * *} \\
(0.031)\end{array}$ & $\begin{array}{c}-0.177^{* * *} \\
(0.031)\end{array}$ \\
\hline Fem. and & & & & & 0.013 & 0.083 & 0.011 & 0.001 \\
\hline married head & & & & & $(0.095)$ & $(0.114)$ & $(0.096)$ & $(0.098)$ \\
\hline Male and non & & & & & $-0.099^{* * *}$ & $-0.189^{* * *}$ & $-0.094^{* *}$ & $-0.094^{* *}$ \\
\hline married head & & & & & $(0.037)$ & $(0.038)$ & $(0.037)$ & (0.036) \\
\hline $\log ($ size & & & & & -0.022 & $-0.357^{* * *}$ & -0.019 & $\begin{array}{c}-0.008 \\
\end{array}$ \\
\hline of $\mathrm{HH})$ & & & & & $(0.030)$ & $(0.035)$ & $(0.030)$ & $(0.028)$ \\
\hline Split-off & & & & & $0.078^{* *}$ & 0.007 & $0.075^{* *}$ & 0.017 \\
\hline $\mathrm{HH}$ & & & & & $(0.034)$ & (0.034) & (0.034) & $(0.030)$ \\
\hline Avg educ. & & & & & $0.087^{* * *}$ & $0.048^{* * *}$ & $0.085^{* * *}$ & $0.073^{* * *}$ \\
\hline $\mathrm{HH}$ & & & & & $(0.010)$ & $(0.010)$ & (0.010) & (0.009) \\
\hline Rainfall & & & $0.055^{* * *}$ & $0.059^{* * *}$ & & & $0.040^{*}$ & $0.047^{* *}$ \\
\hline anomalies & & & $(0.019)$ & $(0.019)$ & & & (0.019) & $(0.020)$ \\
\hline Constant & $12.824^{* * *}$ & $12.246^{* * *}$ & $12.807^{* * *}$ & $12.282^{* * *}$ & $12.773^{* * *}$ & $12.122^{* * *}$ & $12.768^{* * *}$ & $12.274^{* * *}$ \\
\hline & $(0.016)$ & $(0.036)$ & (0.017) & $(0.037)$ & $(0.123)$ & $(0.095)$ & $(0.123)$ & $(0.106)$ \\
\hline Observations & 5,230 & 5,230 & 5,230 & 5,230 & 5,230 & 5,131 & 5,230 & 5,230 \\
\hline $\mathrm{R}$-squared & 0.194 & 0.316 & 0.200 & 0.322 & 0.288 & 0.480 & 0.290 & 0.376 \\
\hline
\end{tabular}

Notes: Robust standard errors clustered at the initial village level in parentheses. ${ }^{*},{ }^{* *},{ }^{* * *}$ : significant at $10 \%, 5 \%$, and $1 \%$, respectively. The sample includes all migrants. $\mathrm{HH}=$ Household. 
Table B.5: Detailed results for panel B of the main results (Table 2)

\begin{tabular}{|c|c|c|c|c|c|c|c|c|}
\hline \multirow[b]{2}{*}{ Dep. var. } & (1) & (2) & (3) & (4) & (5) & (6) & (7) & (8) \\
\hline & \multicolumn{8}{|c|}{ Real consumption per adult equivalent, 1991 and 2010} \\
\hline \multirow[t]{2}{*}{$R I_{v, t}$} & 0.012 & 0.064 & 0.017 & $0.085^{* *}$ & $0.081^{* *}$ & $0.115^{* * *}$ & $0.078^{* *}$ & $0.123^{* * *}$ \\
\hline & $(0.040)$ & $(0.040)$ & $(0.040)$ & $(0.037)$ & $(0.034)$ & $(0.036)$ & $(0.033)$ & $(0.035)$ \\
\hline Age of & & & & & -0.004 & -0.003 & -0.004 & -0.003 \\
\hline head & & & & & $(0.005)$ & $(0.004)$ & $(0.005)$ & $(0.004)$ \\
\hline Age of & & & & & 0.000 & 0.000 & 0.000 & 0.000 \\
\hline head $^{2}$ & & & & & $(0.000)$ & $(0.000)$ & $(0.000)$ & $(0.000)$ \\
\hline Educ. of & & & & & 0.003 & 0.001 & 0.003 & 0.001 \\
\hline head & & & & & $(0.005)$ & $(0.005)$ & $(0.005)$ & $(0.005)$ \\
\hline Chr. Ill. & & & & & -0.036 & -0.027 & -0.036 & -0.028 \\
\hline of head & & & & & $(0.029)$ & $(0.025)$ & $(0.029)$ & $(0.025)$ \\
\hline Fem. and non & & & & & $-0.138^{* * *}$ & $-0.155^{* * *}$ & $-0.139^{* * *}$ & $-0.155^{* * *}$ \\
\hline married head & & & & & $(0.036)$ & $(0.035)$ & $(0.036)$ & $(0.035)$ \\
\hline Fem. and & & & & & -0.148 & -0.179 & -0.149 & -0.177 \\
\hline married head & & & & & $(0.143)$ & $(0.146)$ & $(0.143)$ & $(0.145)$ \\
\hline Male and non & & & & & $-0.079^{* *}$ & $-0.079^{* *}$ & $-0.081^{* *}$ & $-0.077^{* *}$ \\
\hline married head & & & & & $(0.038)$ & $(0.038)$ & $(0.039)$ & $(0.038)$ \\
\hline $\log ($ size & & & & & -0.038 & -0.030 & -0.038 & -0.031 \\
\hline of $\mathrm{HH})$ & & & & & $(0.028)$ & $(0.027)$ & $(0.028)$ & $(0.027)$ \\
\hline Split-off & & & & & -0.036 & $-0.047^{*}$ & -0.037 & $-0.046^{*}$ \\
\hline $\mathrm{HH}$ & & & & & $(0.026)$ & $(0.027)$ & $(0.026)$ & $(0.027)$ \\
\hline Avg educ. & & & & & $0.093^{* * *}$ & $0.077^{* * *}$ & $0.094^{* * *}$ & $0.076^{* * *}$ \\
\hline of $\mathrm{HH}$ & & & & & $(0.008)$ & $(0.008)$ & $(0.008)$ & $(0.008)$ \\
\hline Rainfall & & & 0.015 & 0.052 & & & -0.009 & 0.019 \\
\hline anomalies & & & $(0.036)$ & $(0.046)$ & & & $(0.031)$ & $(0.039)$ \\
\hline Constant & $12.837^{* * *}$ & $12.532^{* * *}$ & $12.832^{* * *}$ & $12.525^{* * *}$ & $12.862^{* * *}$ & $12.580^{* * *}$ & $12.864^{* * *}$ & $12.579^{* * *}$ \\
\hline & $(0.014)$ & $(0.034)$ & $(0.018)$ & $(0.034)$ & $(0.110)$ & $(0.104)$ & $(0.111)$ & $(0.103)$ \\
\hline Observations & 5,788 & 5,788 & 5,788 & 5,788 & 5,788 & 5,788 & 5,788 & 5,788 \\
\hline R-squared & 0.356 & 0.453 & 0.357 & 0.454 & 0.454 & 0.508 & 0.454 & 0.509 \\
\hline
\end{tabular}

Notes: Robust standard errors clustered at the initial village level in parentheses. ${ }^{*},{ }^{* *},{ }^{* * *}$ : significant at $10 \%, 5 \%$, and $1 \%$, respectively. The sample includes all migrants. $\mathrm{HH}=$ Household. 
Table B.6: Main results, controlling for distance-to-the-border variations

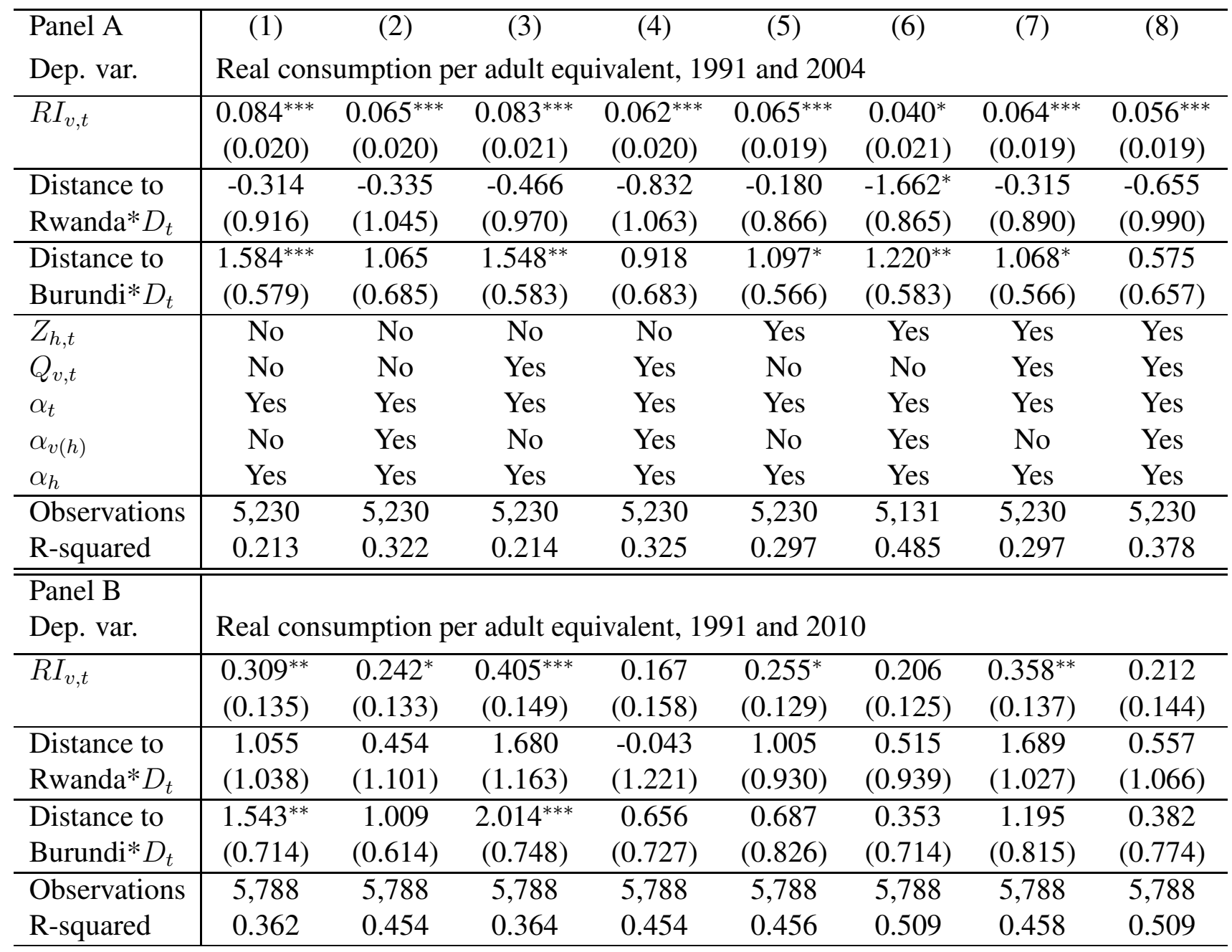

Notes: Robust standard errors clustered at the initial village level in parentheses. ${ }^{*},{ }^{* *},{ }^{* * *}$ : significant at $10 \%, 5 \%$, and $1 \%$, respectively. Distance to borders are expressed in meters $\left(* 10^{6}\right)$. The same regressions are estimated in both panels. The sample includes all migrants. 
Table B.7: Robustness to the exclusion of urban areas

\begin{tabular}{|c|c|c|c|c|c|c|c|c|}
\hline \multirow{2}{*}{$\begin{array}{l}\text { Panel A } \\
\text { Dep. var. }\end{array}$} & (1) & $(2)$ & (3) & (4) & $(5)$ & $(6)$ & (7) & $(8)$ \\
\hline & \multicolumn{8}{|c|}{ Real consumption per adult equivalent, 1991 and 2004} \\
\hline$R I_{v, t}$ & $\begin{array}{c}0.013 \\
(0.026)\end{array}$ & $\begin{array}{c}0.036 \\
(0.025)\end{array}$ & $\begin{array}{c}0.034 \\
(0.023)\end{array}$ & $\begin{array}{l}0.054^{* *} \\
(0.023)\end{array}$ & $\begin{array}{c}0.017 \\
(0.024)\end{array}$ & $\begin{array}{c}0.037 \\
(0.027)\end{array}$ & $\begin{array}{c}0.035 \\
(0.022)\end{array}$ & $\begin{array}{c}0.059^{* * *} \\
(0.022)\end{array}$ \\
\hline$Z_{h, t}$ & No & No & No & No & Yes & Yes & Yes & Yes \\
\hline$Q_{v, t}$ & No & No & Yes & Yes & No & No & Yes & Yes \\
\hline$\alpha_{t}$ & Yes & Yes & Yes & Yes & Yes & Yes & Yes & Yes \\
\hline$\alpha_{v(h)}$ & No & Yes & No & Yes & No & Yes & No & Yes \\
\hline$\alpha_{h}$ & Yes & Yes & Yes & Yes & Yes & Yes & Yes & Yes \\
\hline Observations & 4,230 & 4,230 & 4,230 & 4,230 & 4,230 & 4,160 & 4,230 & 4,230 \\
\hline R-squared & 0.190 & 0.326 & 0.197 & 0.331 & 0.279 & 0.490 & 0.283 & 0.378 \\
\hline $\begin{array}{l}\text { Panel B } \\
\text { Dep. var. }\end{array}$ & \multicolumn{8}{|c|}{ Real consumption per adult equivalent, 1991 and 2010} \\
\hline$R I_{v, t}$ & $\begin{array}{c}0.025 \\
(0.044)\end{array}$ & $\begin{array}{l}0.102^{* *} \\
(0.044)\end{array}$ & $\begin{array}{c}0.031 \\
(0.042)\end{array}$ & $\begin{array}{l}0.106^{* *} \\
(0.041)\end{array}$ & $\begin{array}{l}0.087^{* *} \\
(0.038)\end{array}$ & $\begin{array}{c}0.141^{* * *} \\
(0.041)\end{array}$ & $\begin{array}{l}0.087^{* *} \\
(0.036)\end{array}$ & $\begin{array}{c}0.140^{* * *} \\
(0.038)\end{array}$ \\
\hline Observations & 4,790 & 4,790 & 4,790 & 4,790 & 4,790 & 4,790 & 4,790 & 4,790 \\
\hline R-squared & 0.353 & 0.456 & 0.353 & 0.457 & 0.448 & 0.506 & 0.448 & 0.506 \\
\hline
\end{tabular}

Notes: Robust standard errors clustered at the initial village level in parentheses. ${ }^{*},{ }^{* *},{ }^{* *}$ : significant at $10 \%, 5 \%$, and $1 \%$, respectively. The same regressions are estimated in both panels. The sample includes all migrants.

Table B.8: Robustness to the exclusion of migrants outside of Kagera

\begin{tabular}{|c|c|c|c|c|c|c|c|c|}
\hline $\begin{array}{l}\text { Panel A } \\
\text { Dep. var. }\end{array}$ & \multicolumn{8}{|c|}{ Real consumption per adult equivalent, 1991 and 2004} \\
\hline$R I_{v, t}$ & $\begin{array}{c}0.019 \\
(0.021)\end{array}$ & $\begin{array}{c}0.032 \\
(0.020)\end{array}$ & $\begin{array}{c}0.037^{*} \\
(0.019)\end{array}$ & $\begin{array}{c}0.053^{* * *} \\
(0.019)\end{array}$ & $\begin{array}{c}0.025 \\
(0.019)\end{array}$ & $\begin{array}{c}0.033 \\
(0.022)\end{array}$ & $\begin{array}{l}0.039^{* *} \\
(0.018)\end{array}$ & $\begin{array}{c}0.054^{* * *} \\
(0.018)\end{array}$ \\
\hline$\overline{Z_{h, t}}$ & No & No & No & No & Yes & Yes & Yes & Yes \\
\hline$Q_{v, t}$ & No & No & Yes & Yes & No & No & Yes & Yes \\
\hline$\alpha_{t}$ & Yes & Yes & Yes & Yes & Yes & Yes & Yes & Yes \\
\hline$\alpha_{v(h)}$ & No & Yes & No & Yes & No & Yes & No & Yes \\
\hline$\alpha_{h}$ & Yes & Yes & Yes & Yes & Yes & Yes & Yes & Yes \\
\hline Observations & 4,670 & 4,670 & 4,670 & 4,670 & 4,670 & 4,670 & 4,670 & 4,670 \\
\hline R-squared & 0.159 & 0.213 & 0.165 & 0.221 & 0.229 & 0.406 & 0.233 & 0.276 \\
\hline $\begin{array}{l}\text { Panel B } \\
\text { Dep. var. }\end{array}$ & \multicolumn{8}{|c|}{ Real consumption per adult equivalent, 1991 and 2010} \\
\hline$R I_{v, t}$ & $\begin{array}{c}0.068 \\
(0.041)\end{array}$ & $\begin{array}{c}0.066 \\
(0.040)\end{array}$ & $\begin{array}{l}0.084^{* *} \\
(0.040)\end{array}$ & $\begin{array}{c}0.079^{* *} \\
(0.039)\end{array}$ & $\begin{array}{c}0.119^{* * *} \\
(0.036)\end{array}$ & $\begin{array}{c}0.117^{* * *} \\
(0.036)\end{array}$ & $\begin{array}{c}0.121^{* * *} \\
(0.034)\end{array}$ & $\begin{array}{c}0.119^{* * *} \\
(0.035)\end{array}$ \\
\hline Observations & 4,912 & 4,912 & 4,912 & 4,912 & 4,912 & 4,912 & 4,912 & 4,912 \\
\hline R-squared & 0.314 & 0.353 & 0.315 & 0.353 & 0.383 & 0.412 & 0.383 & 0.412 \\
\hline
\end{tabular}

Notes: Robust standard errors clustered at the initial village level in parentheses. ${ }^{*},{ }^{* *},{ }^{* * *}$ : significant at $10 \%, 5 \%$, and $1 \%$, respectively. The same regressions are estimated in both panels. The sample excludes households migrating outside of Kagera. 
Table B.9: Robustness to the exclusion of all households having moved outside their original village

\begin{tabular}{|c|c|c|c|c|}
\hline $\begin{array}{l}\text { Panel A } \\
\text { Dep. var. }\end{array}$ & $\begin{array}{c}(1) \\
\text { Real cor }\end{array}$ & $\begin{array}{l}(2) \\
\text { umptior }\end{array}$ & $\begin{array}{c}\text { (3) } \\
\text { per adult }\end{array}$ & $\begin{array}{c}(4) \\
\text { th, } 1991 \text { and } 2004\end{array}$ \\
\hline$R I_{v, t}$ & $\begin{array}{c}0.027 \\
(0.025)\end{array}$ & $\begin{array}{l}0.055^{* *} \\
(0.025)\end{array}$ & $\begin{array}{c}0.035 \\
(0.024)\end{array}$ & $\begin{array}{l}0.058^{* *} \\
(0.023)\end{array}$ \\
\hline$Z_{h, t}$ & No & No & Yes & Yes \\
\hline$Q_{v, t}$ & No & Yes & No & Yes \\
\hline$\alpha_{t}$ & Yes & Yes & Yes & Yes \\
\hline$\alpha_{h}$ & Yes & Yes & Yes & Yes \\
\hline Observations & 3,614 & 3,614 & 3,614 & 3,614 \\
\hline R-squared & 0.134 & 0.145 & 0.196 & 0.204 \\
\hline $\begin{array}{l}\text { Panel B } \\
\text { Dep. var. }\end{array}$ & \multicolumn{4}{|c|}{ Real consumption per adult equivalent, 1991 and 2010} \\
\hline$R I_{v, t}$ & $\begin{array}{c}0.064 \\
(0.044)\end{array}$ & $\begin{array}{l}0.074^{*} \\
(0.043)\end{array}$ & $\begin{array}{l}0.102^{* *} \\
(0.040)\end{array}$ & $\begin{array}{c}0.105^{* * *} \\
(0.039)\end{array}$ \\
\hline Observations & 3,194 & 3,194 & 3,194 & 3,194 \\
\hline R-squared & 0.295 & 0.296 & 0.349 & 0.349 \\
\hline
\end{tabular}

Notes: Robust standard errors clustered at the initial village level in parentheses. ${ }^{*},{ }^{* *},{ }^{* * *}$ : significant at $10 \%, 5 \%$, and $1 \%$, respectively. The same regressions are estimated in both panels. The sample excludes households having moved outside of their original village within or outside of Kagera. 
Table B.10: Robustness to alternative dependent variables

\begin{tabular}{|c|c|c|c|c|c|c|}
\hline \multirow{3}{*}{$\begin{array}{l}\text { Panel A } \\
\text { Dep. var. } \\
\text { Type }\end{array}$} & (1) & (2) & (3) & (4) & $(5)$ & $(6)$ \\
\hline & \multicolumn{6}{|c|}{ Real consumption per adult equivalent, 1991 and 2004} \\
\hline & \multicolumn{2}{|c|}{$\begin{array}{c}\text { Food } \\
\text { consumption }\end{array}$} & \multicolumn{2}{|c|}{$\begin{array}{l}\text { Non-Food } \\
\text { consumption }\end{array}$} & \multicolumn{2}{|c|}{$\begin{array}{l}\text { Excl. self-produced } \\
\text { consumption }\end{array}$} \\
\hline$R I_{v, t}$ & $\begin{array}{c}0.022 \\
(0.019)\end{array}$ & $\begin{array}{l}0.040^{* *} \\
(0.018)\end{array}$ & $\begin{array}{c}0.067^{* * *} \\
(0.024)\end{array}$ & $\begin{array}{c}0.085^{* * *} \\
(0.024)\end{array}$ & $\begin{array}{c}0.029 \\
(0.019)\end{array}$ & $\begin{array}{l}0.045^{* *} \\
(0.019)\end{array}$ \\
\hline$Z_{h, t}$ & Yes & Yes & Yes & Yes & Yes & Yes \\
\hline$Q_{v, t}$ & No & Yes & No & Yes & No & Yes \\
\hline$\alpha_{t}$ & Yes & Yes & Yes & Yes & Yes & Yes \\
\hline$\alpha_{v(h)}$ & Yes & Yes & Yes & Yes & Yes & Yes \\
\hline$\alpha_{h}$ & Yes & Yes & Yes & Yes & Yes & Yes \\
\hline Observations & 5,230 & 5,230 & 5,230 & 5,230 & 5,054 & 5,054 \\
\hline R-squared & 0.160 & 0.244 & 0.402 & 0.474 & 0.269 & 0.355 \\
\hline $\begin{array}{l}\text { Panel B } \\
\text { Dep. var. }\end{array}$ & Real co & umption & adult $\mathrm{e}$ & iivalent & 91 and 2 & \\
\hline$R I_{v, t}$ & $\begin{array}{l}0.091^{* *} \\
(0.034)\end{array}$ & $\begin{array}{c}0.144^{* * *} \\
(0.042)\end{array}$ & $\begin{array}{c}0.107^{* *} \\
(0.041)\end{array}$ & $\begin{array}{c}0.139^{* * *} \\
(0.032)\end{array}$ & $\begin{array}{c}0.072^{* *} \\
(0.031)\end{array}$ & $\begin{array}{c}0.120^{* * *} \\
(0.032)\end{array}$ \\
\hline Observations & 5,788 & 5,788 & 5,788 & 5,788 & 5,787 & 5,787 \\
\hline R-squared & 0.233 & 0.301 & 0.588 & 0.626 & 0.291 & 0.373 \\
\hline
\end{tabular}

Notes: Robust standard errors clustered at the initial village level in parentheses. ${ }^{*},{ }^{* *},{ }^{* * *}$ : significant at $10 \%, 5 \%$, and $1 \%$, respectively. The same regressions are estimated in both panels. The sample excludes households migrating outside of Kagera. 
Table B.11: Robustness to alternative (standardized) refugee index $(\gamma=1,0.5,2,3)$

\begin{tabular}{|c|c|c|c|c|c|c|c|c|}
\hline $\begin{array}{l}\text { Panel A } \\
\text { Dep. var. }\end{array}$ & \multicolumn{8}{|c|}{ Real consumption per adult equivalent, 1991 and 2004} \\
\hline $\begin{array}{l}\text { Alternative } \\
R I_{v, t}\end{array}$ & \multicolumn{8}{|c|}{$R I_{v, t}=\log \left(\sum_{c=1}^{13} \frac{p o p_{c}}{d_{v, c}^{\gamma}}\right)$, standardized } \\
\hline $\begin{array}{l}\text { Alternative } \\
R I_{v, t}\end{array}$ & $\begin{array}{l}0.031^{*} \\
(0.018)\end{array}$ & $\begin{array}{c}0.049^{* * *} \\
(0.018)\end{array}$ & $\begin{array}{c}0.245 \\
(0.152)\end{array}$ & $\begin{array}{c}0.411^{\text {*** }}(0.149)\end{array}$ & $\begin{array}{l}0.022^{* *} \\
(0.011)\end{array}$ & $\begin{array}{l}0.026^{* *} \\
(0.010)\end{array}$ & $\begin{array}{l}0.020^{*} \\
(0.011)\end{array}$ & $\begin{array}{l}0.023^{* *} \\
(0.010)\end{array}$ \\
\hline$Z_{h, t}$ & Yes & Yes & Yes & Yes & Yes & Yes & Yes & Yes \\
\hline$Q_{v, t}$ & No & Yes & No & Yes & No & Yes & No & Yes \\
\hline$\alpha_{t}$ & Yes & Yes & Yes & Yes & Yes & Yes & Yes & Yes \\
\hline$\alpha_{v(h)}$ & Yes & Yes & Yes & Yes & Yes & Yes & Yes & Yes \\
\hline$\alpha_{h}$ & Yes & Yes & Yes & Yes & Yes & Yes & Yes & Yes \\
\hline Observations & 5,230 & 5,230 & 5,230 & 5,230 & 5,230 & 5,230 & 5,230 & 5,230 \\
\hline R-squared & 0.290 & 0.376 & 0.290 & 0.376 & 0.291 & 0.376 & 0.291 & 0.375 \\
\hline $\begin{array}{l}\text { Panel B } \\
\text { Dep. var. }\end{array}$ & \multicolumn{8}{|c|}{ Real consumption per adult equivalent, 1991 and 2010} \\
\hline $\begin{array}{l}\text { Alternative } \\
R I_{v, t}\end{array}$ & $\begin{array}{l}0.078^{* *} \\
(0.033)\end{array}$ & $\begin{array}{c}0.123^{* * *} \\
(0.035)\end{array}$ & $\begin{array}{c}0.549^{* *} \\
(0.249)\end{array}$ & $\begin{array}{c}0.894^{* * *} \\
(0.251)\end{array}$ & $\begin{array}{l}0.021^{*} \\
(0.011)\end{array}$ & $\begin{array}{l}0.028^{* *} \\
(0.013)\end{array}$ & $\begin{array}{l}0.013^{*} \\
(0.008)\end{array}$ & $\begin{array}{l}0.018^{*} \\
(0.009)\end{array}$ \\
\hline Observations & 5,788 & 5,788 & 5,788 & 5,788 & 5,788 & 5,788 & 5,788 & 5,788 \\
\hline R-squared & 0.454 & 0.509 & 0.454 & 0.508 & 0.454 & 0.507 & 0.453 & 0.506 \\
\hline
\end{tabular}

Notes: Robust standard errors clustered at the initial village level in parentheses. ${ }^{*},{ }^{* *},{ }^{* * *}$ : significant at $10 \%, 5 \%$, and $1 \%$, respectively. The same regressions are estimated in both panels. To ease comparison, all coefficients are standardized. The sample includes all migrants. 
Table B.12: Robustness to alternative refugee indexes (restricted to refugees from Rwanda or Burundi, no $\log$ transformation, and a dummy variable for high-refugee area)

\begin{tabular}{|c|c|c|c|c|c|c|c|c|}
\hline \multirow{2}{*}{$\begin{array}{l}\text { Panel A } \\
\text { Dep. var. }\end{array}$} & (1) & (2) & (3) & (4) & $(5)$ & (6) & (7) & $(8)$ \\
\hline & \multicolumn{8}{|c|}{ Real consumption per adult equivalent, 1991 and 2004} \\
\hline $\begin{array}{l}\text { Alternative } \\
R I_{v, t}\end{array}$ & \multicolumn{2}{|c|}{$\begin{array}{l}\text { Restricted to refugees } \\
\text { from Rwanda }\end{array}$} & \multicolumn{2}{|c|}{$\begin{array}{l}\text { Restricted to refugees } \\
\text { from Burundi }\end{array}$} & \multicolumn{2}{|c|}{ No Log } & \multicolumn{2}{|c|}{$\begin{array}{c}\text { Dummy for } \\
\text { high-refugee area }\end{array}$} \\
\hline $\begin{array}{l}\text { Alternative } \\
R I_{v, t}\end{array}$ & $\begin{array}{c}0.051^{*} \\
(0.028)\end{array}$ & $\begin{array}{c}0.080^{* * *} \\
(0.028)\end{array}$ & $\begin{array}{c}0.028 \\
(0.017)\end{array}$ & $\begin{array}{l}0.043^{* *} \\
(0.016)\end{array}$ & $\begin{array}{l}0.002^{* *} \\
(0.001)\end{array}$ & $\begin{array}{c}0.002^{* * *} \\
(0.001)\end{array}$ & $\begin{array}{c}0.035 \\
(0.053)\end{array}$ & $\begin{array}{c}0.120^{*} \\
(0.062)\end{array}$ \\
\hline$Z_{h, t}$ & Yes & Yes & Yes & Yes & Yes & Yes & Yes & Yes \\
\hline$Q_{v, t}$ & No & Yes & No & Yes & No & Yes & No & Yes \\
\hline$\alpha_{t}$ & Yes & Yes & Yes & Yes & Yes & Yes & Yes & Yes \\
\hline$\alpha_{v(h)}$ & Yes & Yes & Yes & Yes & Yes & Yes & Yes & Yes \\
\hline$\alpha_{h}$ & Yes & Yes & Yes & Yes & Yes & Yes & Yes & Yes \\
\hline Observations & 5,230 & 5,230 & 5,230 & 5,230 & 5,230 & 5,230 & 5,230 & 5,230 \\
\hline R-squared & 0.290 & 0.377 & 0.290 & 0.376 & 0.291 & 0.376 & 0.290 & 0.376 \\
\hline $\begin{array}{l}\text { Panel B } \\
\text { Dep. var. }\end{array}$ & Real con & mption per & dult equi & ent, 1991 a & d 2010 & & & \\
\hline $\begin{array}{l}\text { Alternative } \\
R I_{v, t}\end{array}$ & $\begin{array}{l}0.081^{*} \\
(0.044)\end{array}$ & $\begin{array}{c}0.138^{* * *} \\
(0.043)\end{array}$ & $\begin{array}{l}0.051^{\text {*** }} \\
(0.019)\end{array}$ & $\begin{array}{c}0.072^{* * *} \\
(0.020)\end{array}$ & $\begin{array}{c}0.005^{* * *} \\
(0.002)\end{array}$ & $\begin{array}{c}0.007^{* * *} \\
(0.002)\end{array}$ & $\begin{array}{c}0.180^{* * *} \\
(0.047)\end{array}$ & $\begin{array}{c}0.216^{* * *} \\
(0.052)\end{array}$ \\
\hline Observations & 5,788 & 5,788 & 5,788 & 5,788 & 5,788 & 5,788 & 5,788 & 5,788 \\
\hline R-squared & 0.454 & 0.508 & 0.455 & 0.508 & 0.455 & 0.508 & 0.456 & 0.509 \\
\hline
\end{tabular}

Notes: Robust standard errors clustered at the initial village level in parentheses. ${ }^{*},{ }^{* *},{ }^{* *}$ : significant at $10 \%, 5 \%$, and $1 \%$, respectively. The same regressions are estimated in both panels. To ease comparison, all coefficients are standardized (with the exceptions of the refugee index without logarithm transformation and the dummy variable for high-refugee areas). The sample includes all migrants. 
Table B.13: Migration regressions (probit model)

\begin{tabular}{|c|c|c|c|c|c|c|}
\hline $\begin{array}{l}\text { Panel A } \\
\text { Dep. var. }\end{array}$ & \multicolumn{3}{|c|}{$\begin{array}{l}\text { Migration, } 1991 \text { and } 2004 \\
\text { outside of Kagera }\end{array}$} & \multicolumn{3}{|c|}{$\begin{array}{l}\text { Migration, } 1991 \text { and } 2004 \\
\text { all, incl. within Kagera }\end{array}$} \\
\hline$R I_{v, t}$ & $\begin{array}{c}0.014 \\
(0.010)\end{array}$ & $\begin{array}{c}0.016 \\
(0.010)\end{array}$ & $\begin{array}{c}0.016 \\
(0.012)\end{array}$ & $\begin{array}{c}0.010 \\
(0.016)\end{array}$ & $\begin{array}{c}0.012 \\
(0.014)\end{array}$ & $\begin{array}{l}-0.003 \\
(0.013)\end{array}$ \\
\hline $\begin{array}{l}Z_{h, 1991} \\
Q_{v, 1991} \\
\text { Observations }\end{array}$ & $\begin{array}{c}\text { No } \\
\text { No } \\
2,615\end{array}$ & $\begin{array}{c}\text { No } \\
\text { Yes } \\
2,615\end{array}$ & $\begin{array}{c}\text { Yes } \\
\text { Yes } \\
2,615\end{array}$ & $\begin{array}{c}\text { No } \\
\text { No } \\
2,615\end{array}$ & $\begin{array}{c}\text { No } \\
\text { Yes } \\
2,615\end{array}$ & $\begin{array}{c}\text { Yes } \\
\text { Yes } \\
2,615\end{array}$ \\
\hline $\begin{array}{l}\text { Panel B } \\
\text { Dep. var. }\end{array}$ & \multicolumn{3}{|c|}{$\begin{array}{l}\text { Migration, } 1991 \text { and } 2004 \\
\text { outside of Kagera }\end{array}$} & \multicolumn{3}{|c|}{$\begin{array}{l}\text { Migration, } 1991 \text { and } 2004 \\
\text { all, incl. within Kagera }\end{array}$} \\
\hline for_ref & $\begin{array}{c}-0.106^{* * *} \\
(0.028)\end{array}$ & $\begin{array}{c}-0.094^{* *} \\
(0.042)\end{array}$ & $\begin{array}{l}-0.061^{* *} \\
(0.026)\end{array}$ & $\begin{array}{l}-0.061^{* *} \\
(0.027)\end{array}$ & $\begin{array}{l}-0.030 \\
(0.032)\end{array}$ & $\begin{array}{c}0.023 \\
(0.029)\end{array}$ \\
\hline $\begin{array}{l}Z_{h, 1991} \\
Q_{v, 1991} \\
\text { Observations }\end{array}$ & $\begin{array}{c}\text { No } \\
\text { No } \\
2,894\end{array}$ & $\begin{array}{c}\text { No } \\
\text { Yes } \\
2,894\end{array}$ & $\begin{array}{c}\text { Yes } \\
\text { Yes } \\
2,894\end{array}$ & $\begin{array}{c}\text { No } \\
\text { No } \\
2,894\end{array}$ & $\begin{array}{c}\text { No } \\
\text { Yes } \\
2,894\end{array}$ & $\begin{array}{c}\text { Yes } \\
\text { Yes } \\
2,894\end{array}$ \\
\hline
\end{tabular}

Notes: Robust standard errors clustered at the initial village level in parentheses. ${ }^{*},{ }^{* *},{ }^{* * *}$ : significant at $10 \%, 5 \%$, and $1 \%$, respectively. The same regressions are estimated in both panels. Average partial effects are reported. 
Table B.14: The location of refugee camps in more accessible areas?

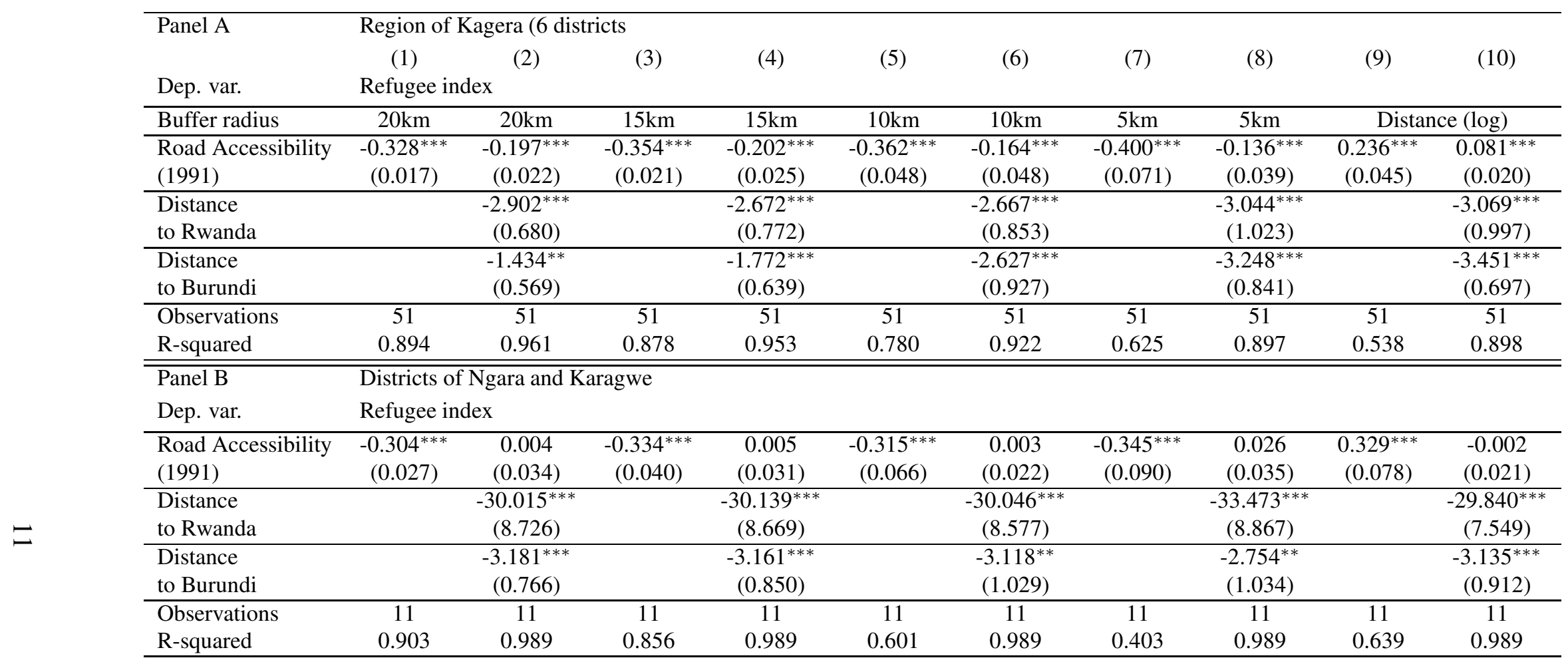

Notes: Robust standard errors in parentheses. ${ }^{*},{ }^{* *},{ }^{* * *}$ : significant at $10 \%, 5 \%$, and $1 \%$, respectively. 
Table B.15: Further analysis of the importance of road accessibility

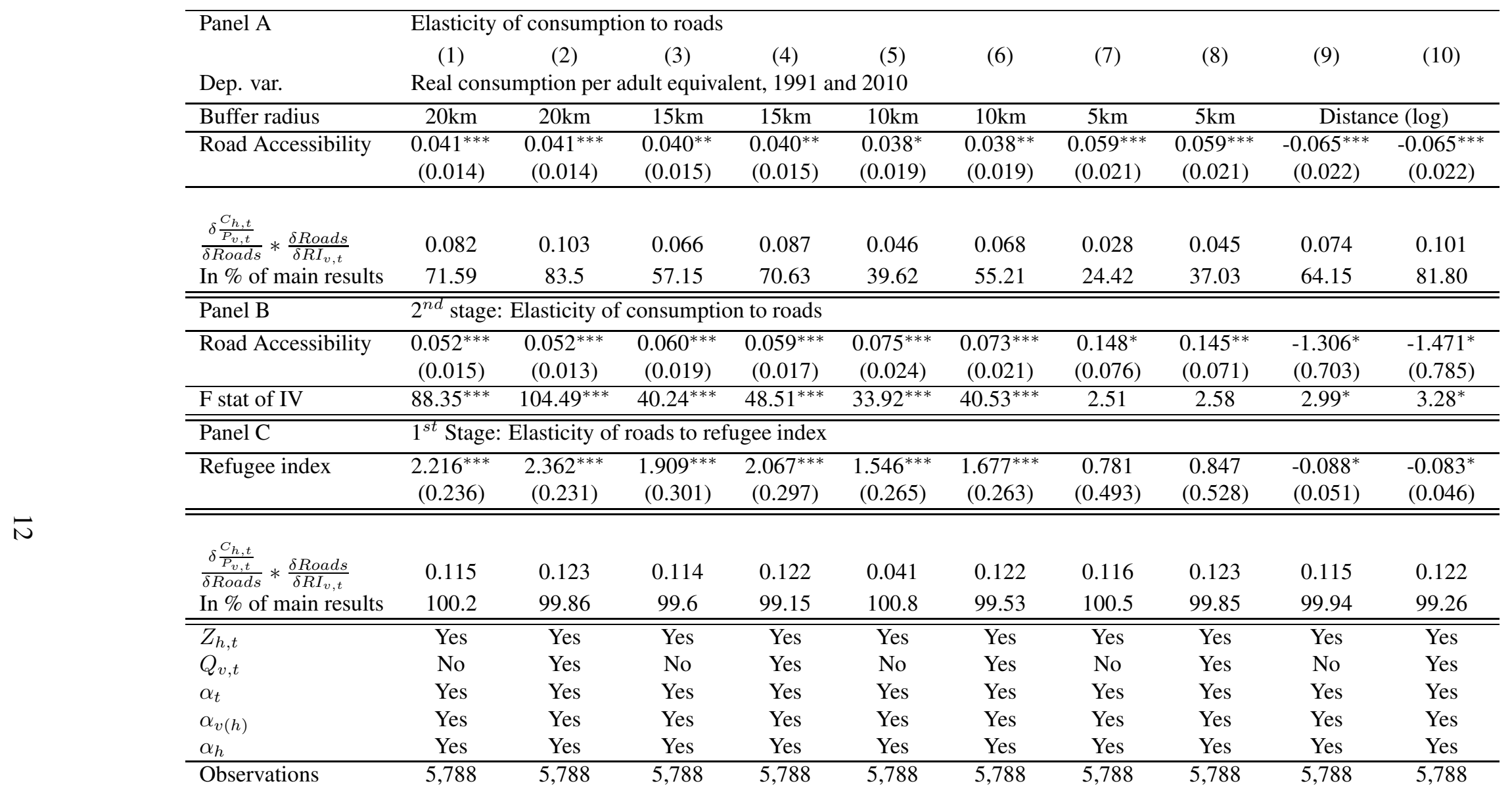

Notes: Robust standard errors in parentheses. ${ }^{*},{ }^{* *},{ }^{* * *}$ : significant at $10 \%, 5 \%$, and $1 \%$, respectively. 